\title{
Floods and climate: emerging perspectives for flood risk assessment and management
}

\author{
B. Merz ${ }^{1}$, J. Aerts ${ }^{2}$, K. Arnbjerg-Nielsen ${ }^{3}$, M. Baldi ${ }^{4}$, A. Becker ${ }^{5}$, A. Bichet ${ }^{6}$, G. Blöschl ${ }^{7}$, L. M. Bouwer ${ }^{8}$, A. Brauer ${ }^{1}$, \\ F. Cioffi ${ }^{9}$, J. M. Delgado ${ }^{10}$, M. Gocht ${ }^{11}$, F. Guzzetti ${ }^{12}$, S. Harrigan ${ }^{13}$, K. Hirschboeck ${ }^{14}$, C. Kilsby ${ }^{15}$, W. Kron ${ }^{16}$, \\ H.-H. Kwon ${ }^{17}$, U. Lall ${ }^{18}$, R. Merz ${ }^{19}$, K. Nissen ${ }^{20}$, P. Salvatti ${ }^{12}$, T. Swierczynski ${ }^{1}$, U. Ulbrich $^{20}$, A. Viglione ${ }^{7}$, \\ P. J. Ward ${ }^{2}$, M. Weiler ${ }^{21}$, B. Wilhelm ${ }^{22}$, and M. Nied ${ }^{1}$ \\ ${ }^{1}$ GFZ German Research Centre for Geosciences, 14473 Potsdam, Germany \\ ${ }^{2}$ Institute for Environmental Studies, VU University Amsterdam, 1081HV Amsterdam, the Netherlands \\ ${ }^{3}$ Dept. of Env. Eng., Technical University of Denmark, Lyngby, Denmark \\ ${ }^{4}$ CNR-Institute of Biometeorology, 00185 Rome, Italy \\ ${ }^{5}$ Deutscher Wetterdienst, Offenbach am Main, Germany \\ ${ }^{6}$ University of Toronto, Physics Department, Toronto, Canada \\ ${ }^{7}$ Institute of Hydraulic Engineering and Water Resources Management, Vienna University of Technology, Vienna, Austria \\ ${ }^{8}$ Deltares, Delft, the Netherlands \\ ${ }^{9}$ DICEA, Department of Civil, Constructional \& Environmental Engineering, University of Rome, La Sapienza, Rome, Italy \\ ${ }^{10}$ University of Potsdam, Institute of Earth and Environmental Science, Potsdam, Germany \\ ${ }^{11}$ Technische Universität Braunschweig, 38106 Braunschweig, Germany \\ ${ }^{12}$ CNR IRPI, 06128 Perugia, Italy \\ ${ }^{13}$ ICARUS, Dept. of Geography, National University of Ireland, Maynooth, Ireland \\ ${ }^{14}$ Laboratory of Tree-Ring Research, University of Arizona, Tucson, Arizona, USA \\ ${ }^{15}$ School of Civil Engineering and Geosciences, Newcastle University, Newcastle, UK \\ ${ }^{16}$ Munich Re, 80802 Munich, Germany \\ ${ }^{17}$ Department of Civil Engineering, Chonbuk National University, Jeonju, Republic of Korea \\ ${ }^{18}$ Dept. of Earth \& Env. Eng., Columbia University, New York, USA \\ ${ }^{19}$ Helmholtz Centre for Environmental Research, Leipzig, Germany \\ ${ }^{20}$ Institute for Meteorology, Freie Universität Berlin, 12165 Berlin, Germany \\ ${ }^{21}$ Chair of Hydrology, Faculty of Environment and Natural Resources, University of Freiburg, Freiburg, Germany \\ ${ }^{22}$ EDYTEM, Université de Savoie, 73376 Le Bourget-du-Lac, France \\ Correspondence to: B. Merz (bmerz@gfz-potsdam.de)
}

Received: 24 January 2014 - Published in Nat. Hazards Earth Syst. Sci. Discuss.: 14 February 2014

Revised: 3 June 2014 - Accepted: 15 June 2014 - Published: 30 July 2014

\begin{abstract}
Flood estimation and flood management have traditionally been the domain of hydrologists, water resources engineers and statisticians, and disciplinary approaches abound. Dominant views have been shaped; one example is the catchment perspective: floods are formed and influenced by the interaction of local, catchment-specific characteristics, such as meteorology, topography and geology. These traditional views have been beneficial, but they have a narrow framing. In this paper we contrast traditional views
\end{abstract}

with broader perspectives that are emerging from an improved understanding of the climatic context of floods. We come to the following conclusions: (1) extending the traditional system boundaries (local catchment, recent decades, hydrological/hydraulic processes) opens up exciting possibilities for better understanding and improved tools for flood risk assessment and management. (2) Statistical approaches in flood estimation need to be complemented by the search for the causal mechanisms and dominant processes in the 
atmosphere, catchment and river system that leave their fingerprints on flood characteristics. (3) Natural climate variability leads to time-varying flood characteristics, and this variation may be partially quantifiable and predictable, with the perspective of dynamic, climate-informed flood risk management. (4) Efforts are needed to fully account for factors that contribute to changes in all three risk components (hazard, exposure, vulnerability) and to better understand the interactions between society and floods. (5) Given the global scale and societal importance, we call for the organization of an international multidisciplinary collaboration and datasharing initiative to further understand the links between climate and flooding and to advance flood research.

\section{Introduction}

Flood estimation and flood management have a long history, over which dominant views have been shaped. One example is the river basin paradigm. In this, floods are seen from the catchment perspective; they are formed and influenced by the interaction of local, i.e. catchment-specific, characteristics of meteorology, topography, geology, vegetation, etc. Another traditional view is that floods are essentially random events: typically, for statistical convenience, extreme flood occurrence and magnitude are assumed to correspond to an independent, identically distributed (iid) random process represented by an appropriate probability density function.

During the EGU topical meeting "Floods and Climate: Understanding and exploiting the link between floods and climate" on 4-5 October 2012 in Potsdam, the climate context of floods was discussed: how are floods related to climate and, in particular, to climate variability? To what extent can we take advantage of linkages between climate and floods? The workshop participants felt that, although the traditional views have been beneficial, they have a narrow framing, and that flood estimation and flood management could benefit from a broader perspective. For instance, the local catchment perspective needs to be complemented by the global view, since floods are embedded in a global climate context. The actual flood potential of a catchment and the characteristics of floods may be influenced by global climate mechanisms. Hirschboeck (1987) offered the hypothesis that unusually large floods in drainage basins of all sizes may be related to large-scale atmospheric circulation anomalies. Nakamura et al. (2013) show that 20 major flood events over the last 100 years in the Ohio River basin have nearly identical storm tracks, moisture source and delivery patterns. Such persistent anomalies may in turn reflect modulation of the storm tracks by identifiable climate phenomena such as the El Niño-Southern Oscillation (ENSO) and Pacific Decadal Oscillation (PDO). Consequently, it seems necessary to complement the local catchment perspective with a global view in order to investigate whether floods are purely random and whether the widespread iid assumption holds, and to develop flood risk assessment methods which are capable of taking advantage of such extended perspectives.

New perspectives are emerging even more clearly in the field of flood risk management. Traditionally, flood management strategies have focused on reducing the flood hazard, i.e. the probability of flooding. Hence, flood research has centred on the physical processes within catchments and river systems. Over the past two decades there has been a shift from the hazard-focused view to the broader riskbased perspective, including societal processes and implications (Merz et al., 2010a). Flood disaster risk results from the interaction of hazard, exposure and vulnerability. Hazard represents the probability and intensity of flooding; exposure describes the elements at risk - for example, the people and their assets that may be affected by flooding; and vulnerability describes the susceptibility or propensity of elements at risk to be adversely affected. This concept is at the heart of the Global Assessment Reports of the United Nations Office for Disaster Risk Reduction (UNISDR, 2011, 2013), and the IPCC (2012) SREX report adopted it for analysing risks related to climate change.

It is taken for granted that changes in climate or human interventions in catchments and river systems may change flood hazard and, as a consequence, flood risk. Within this view, floods are evaluated from a hazard perspective, focusing on hydrologic/hydraulic parameters such as discharge, water level or inundation extent. Societal processes are often neglected, which implicitly means they are assumed to be constant or, if random, a stationary process. However, some socio-economic processes, like population growth and economic development, may change at a faster pace than long-term physical changes (for example, the impacts of climate change on discharge), and exposure and vulnerability to floods can be highly dynamic. Against this background, societal processes need to be addressed within a risk-based approach, where next to the hazard, societal exposure and vulnerability play a decisive role. A particularly interesting question is how space-time variations in flood hazard that may be related to climate variability and change intersect with the changing nature of the flood exposure and vulnerability. As an example, globalization leads to potential pathways of supply chain disruption as seen with the long-duration floods in Thailand (2011); Queensland, Australia (2010, 2011); the Indus River (2010); and the Mississippi River (2012), which led to significant local and global economic impacts.

Table 1 contrasts the traditional narrow framing of floods with the broader perspective that is emerging from an improved understanding of the climatic context of flood generation. The different aspects of Table 1 are closely linked. This becomes obvious in Sect. 2, which focuses on understanding climate-flood linkages. In Sect. 3, we discuss how this broader framing may be used for improved flood estimation and risk management. In particular, we explore how 
Table 1. Contrasting traditional views with emerging perspectives on flood hazard and risk.

\begin{tabular}{|c|c|c|}
\hline Aspect & Traditional view & Emerging perspective \\
\hline \multicolumn{3}{|c|}{ Understanding climate-flood linkages } \\
\hline Randomness & $\begin{array}{l}\text { Random: floods are random events } \\
\text { with flood magnitude quantified by a } \\
\text { probability distribution. }\end{array}$ & $\begin{array}{l}\text { Causal: flood occurrence and magnitude } \\
\text { depend on a causal network of processes } \\
\text { in atmosphere, catchment and river } \\
\text { systems. A fraction of the flood variability is } \\
\text { described by deterministic processes: for } \\
\text { example, by using climate information as } \\
\text { co-variates in flood probability distributions. }\end{array}$ \\
\hline Spatial perspective & $\begin{array}{l}\text { Local: floods are events that can be } \\
\text { described fully by processes on a } \\
\text { catchment scale. }\end{array}$ & $\begin{array}{l}\text { Global: floods occur within the spatial } \\
\text { framework of large-scale circulation } \\
\text { patterns and global climate mechanisms. }\end{array}$ \\
\hline $\begin{array}{l}\text { Natural variability } \\
\text { and floods }\end{array}$ & $\begin{array}{l}\text { Stationary: flood characteristics are } \\
\text { stationary and represent the long-term } \\
\text { natural variability of the climate-- } \\
\text { catchment system. }\end{array}$ & $\begin{array}{l}\text { Time-varying: flood characteristics change } \\
\text { in time due to climate variability at } \\
\text { different timescales. }\end{array}$ \\
\hline $\begin{array}{l}\text { Temporal } \\
\text { perspective }\end{array}$ & $\begin{array}{l}\text { Recent: flood characteristics result } \\
\text { from current catchment } \\
\text { characteristics and are derived from } \\
\text { recent observations. }\end{array}$ & $\begin{array}{l}\text { Long-term: flood characteristics result } \\
\text { from the long-term interplay of climate, } \\
\text { geology, topography, vegetation (biology), } \\
\text { and humans. To fully understand floods, } \\
\text { this long-term interplay has to be disentangled. }\end{array}$ \\
\hline
\end{tabular}

Exploiting climate-flood linkages

\begin{tabular}{|c|c|c|}
\hline Flood estimation & $\begin{array}{l}\text { Process-neutral: flood estimation } \\
\text { does not differentiate between } \\
\text { different flood event types and } \\
\text { processes. Flood frequency analysis } \\
\text { is based on iid assumption. }\end{array}$ & $\begin{array}{l}\text { Process-based: flood events of different } \\
\text { types occur in a given catchment. } \\
\text { Knowledge on flood generation processes } \\
\text { provides information on flood probability estimation. }\end{array}$ \\
\hline $\begin{array}{l}\text { Flood projections } \\
\text { under climate } \\
\text { change }\end{array}$ & $\begin{array}{l}\text { Model chain: flood scenarios are the } \\
\text { result of model chains, from } \\
\text { emission scenarios to climate } \\
\text { models to flood frequency estimation. }\end{array}$ & $\begin{array}{l}\text { Model-chain-augmented: in addition to } \\
\text { model chains, a range of approaches for } \\
\text { assessing climate-related flood changes } \\
\text { are used, such as assessing historical } \\
\text { climate variability, or using ocean source-- } \\
\text { atmospheric moisture transport-flood linkages. }\end{array}$ \\
\hline $\begin{array}{l}\text { Flood risk } \\
\text { management }\end{array}$ & $\begin{array}{l}\text { Hazard-focused, static: flood } \\
\text { management focuses on flood } \\
\text { hazard reduction within a static } \\
\text { framework, principally using } \\
\text { structural or zoning flood proofing or } \\
\text { financial instruments (insurance). }\end{array}$ & $\begin{array}{l}\text { Risk-oriented, dynamic: risk management } \\
\text { takes into account changing hazard, } \\
\text { exposure and vulnerability, and the } \\
\text { combined application of financial, } \\
\text { structural and non-structural measures. } \\
\text { The best way to mitigate floods depends } \\
\text { on how well changes in flood risk can be } \\
\text { predicted at short and long timescales. }\end{array}$ \\
\hline
\end{tabular}

an improved process-based understanding of climate-flood linkages at multiple scales can be exploited to address critical management and societal issues in a rapidly changing world.

This paper is based on the EGU topical meeting "Floods and Climate: Understanding and exploiting the link between floods and climate" in October 2012 in Potsdam. This interdisciplinary meeting was dedicated to discuss innovative approaches and to develop new perspectives in the broad field of how floods are embedded in the climate context. This paper is the attempt to organize the different aspects in this field within one paper, putting emphasis on how different ideas have been emerging during the last years and how they can be connected.

\subsection{Understanding climate-flood linkages}

Climate-flood linkages operate across multiple spatial and temporal scales determined by (i) the nature of the 
meteorological and climatic processes that drive the atmospheric components of the hydrologic cycle and (ii) the nature of the hydrologic land-surface and subsurface processes within which a flood develops. As implied in Table 1, the traditional approach for linking atmospheric components to flood analysis has been primarily hydro-meteorological, i.e. framed by local weather events of recent decades interacting with current catchment characteristics. The emerging view of climate-flood linkages is process driven and seeks to understand and analyse flood events in the context of their long-term history of variation - in magnitude, frequency, and seasonality - and within the climatic framework of the global and regional atmospheric circulation patterns and processes that drive changing combinations of meteorological elements at the catchment scale. In the following, we discuss these contrasting perspectives.

\subsection{Randomness or causality?}

Floods are typically seen as events that are generated by the random superposition of processes in the atmosphere, catchment and river system. The idea of very strong or even complete randomness prevails in the history of flood prediction. Much effort has been spent on describing flood occurrence and magnitude by probability distributions, a large share of the flood research has been focused on statistical aspects, and the role of randomness has been emphasized. This avenue has been shaped by the pioneers of flood frequency analysis; for example, in 1941 Emil Julius Gumbel mentioned the flood estimation problem: "The author believes it is possible to give exact solutions, exactitude being interpreted from the standpoint of the calculus of probabilities." (Gumbel, 1941, p. 163).

Figure 1 provides examples of the atmospheric moisture transport averaged across the top 10 floods over a 60year period in 4 regions of North America. It is clear that there is a distinct large-scale circulation pattern with different moisture sources and storm tracks associated with these extreme events. Such determinism is not restricted to the mid-latitudes. The 2011 persistent flooding in Thailand was marked by five typhoon landings over a period of 100 days, and the typhoon tracks were very similar over this period with a similar area of origin and path. The prevailing $\mathrm{La}$ Niña conditions in the western Pacific (the source region of the storms) and phase of the Madden-Julian Oscillation (2040-day) period are thought to have interacted to produce the convergence of moisture into Thailand per event. To be sure of this, causality may also be found in other aspects of the climate-catchment system. For example, Nied et al. (2013) show that floods in the Elbe catchment in central Europe are preferentially initiated by specific large-scale soil moisture patterns, and Sivapalan et al. (2005) demonstrate that the flood peaks increase notably if seasonality of rainfall and antecedent soil moisture are in phase.

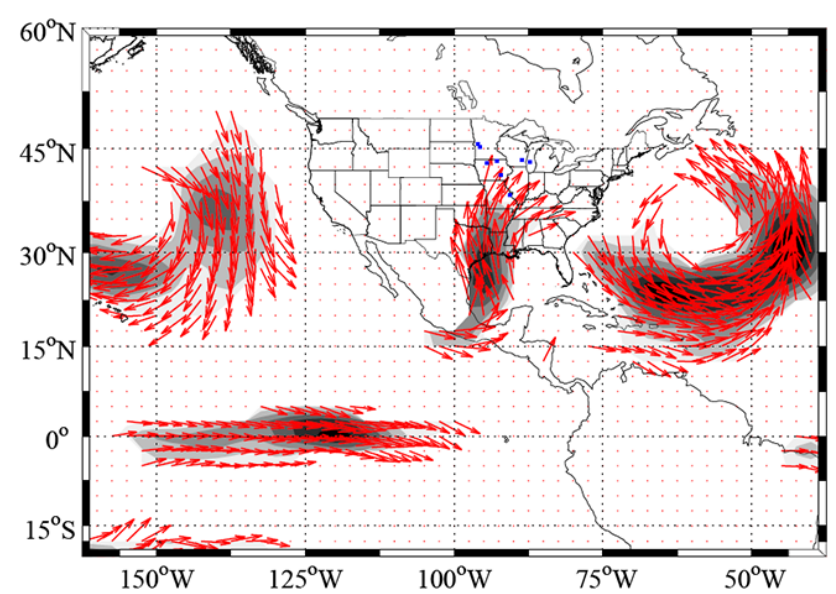

Figure 1. Vertically integrated moisture flux averaged over the dates of the 10 largest floods in the Ohio River basin in North America from 1948 to 2005 . The flux is computed daily over $1000-850 \mathrm{mb}$, using the NOAA-NCEP reanalysis data set. The arrows show the wind direction, and the shading shows the intensity of the moisture flux. Only pixels whose moisture flux magnitude is in the top $5 \%$ of the visible map are shown. Note that a large-scale meridional lowlevel flow into the region is active averaged across these 10 events.

If one takes a causal approach, arguing that flood occurrence and magnitude contain a significant fraction of determinism, then identifying the signatures of major floods in terms of the associated climatic and catchment mechanisms becomes important. A fruitful direction of research could be to identify the dominant mechanisms associated with regional floods, and to see how the occurrence and intensity of those mechanisms lead to the space and time expression of floods. The analysis would move from annual maximum or peak over threshold floods to looking at extreme floods in terms of discharge, volume and duration and their space and time structure over perhaps a season, a decade or longer as could be informed by the nature of the underlying mechanisms. The volume and duration of flooding are directly tied to inundation characteristics and hence represent how the strength and recurrence characteristics of the large-scale atmospheric fluxes that bring moisture into the region interact with catchment hydrologic processes. These in turn determine how the static and dynamic aspects of topography, soils, channel networks and flood control infrastructure process the atmospheric inputs. Given the uncertainties attendant to all these processes, the integrated causal view could provide a basis for better probabilistic modelling of floods from a physical as well as statistical perspective.

\subsection{Local or global?}

Frequently, floods have been understood as local phenomena, driven by the perspective of flood management at the local level, e.g. at the municipal or county scale. Within the last two decades there have been many attempts to reconcile the 


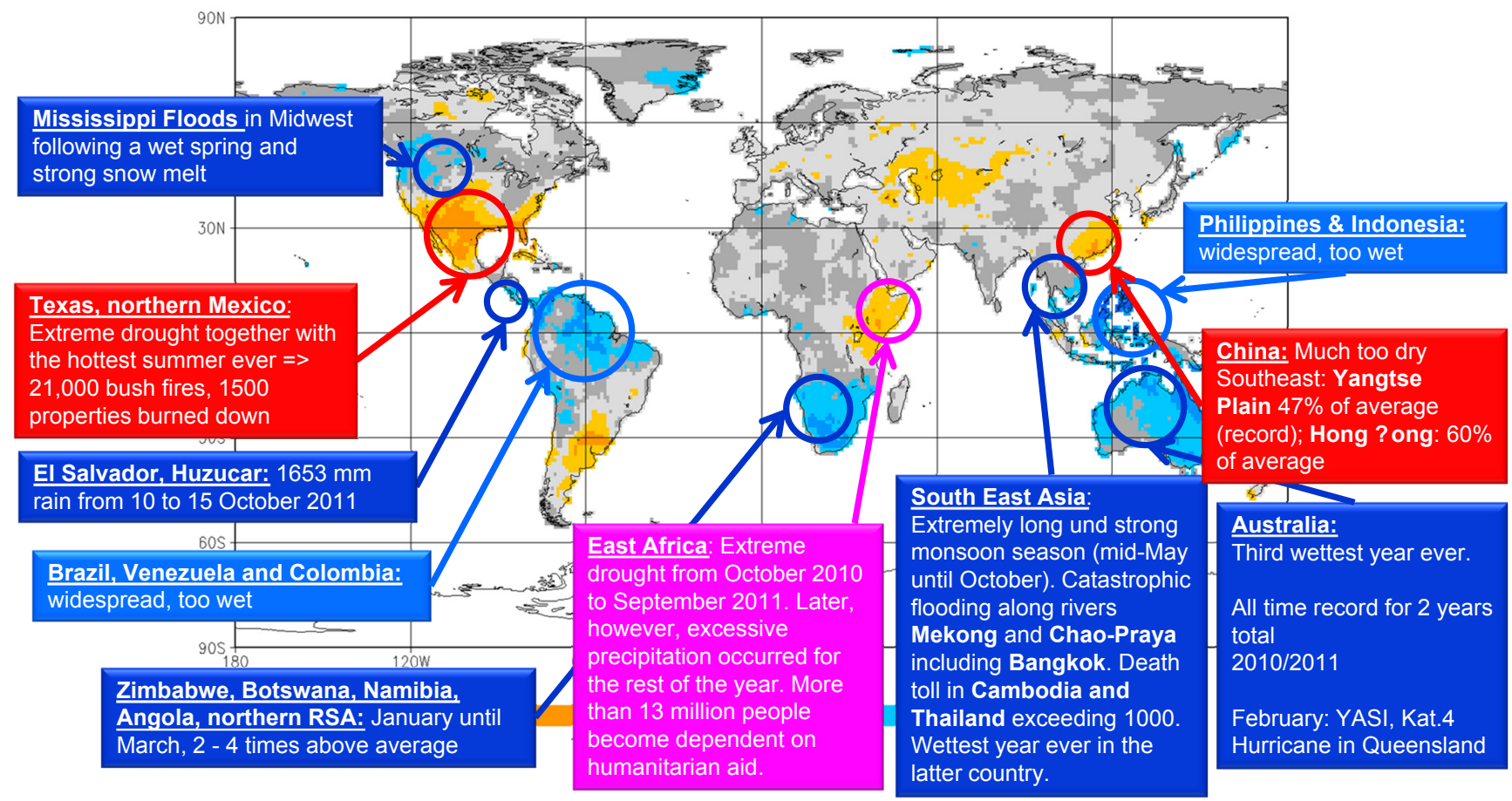

Figure 2. Centennial climatology of ENSO sensitive regions with regard to the global land-surface precipitation from 1901 to 2010 . Blue (red) areas have enhanced (reduced) precipitation during La Niña periods. In addition, the circles and boxes point to extreme hydro-meteorological events (including devastating floods) which occurred during the strong La Niña year 2011.

spatial frame of this societal lens with the traditional hydrological view. Here, floods are considered through the local catchment lens, and are shaped by catchment meteorology, hydrology and river processes. The emerging view extends this spatial framework to the continental and global scale to accommodate the interactions between local flooding and global climate mechanisms.

Probably the most famous and well-studied global linkage between large-scale climate oscillations and hydrometeorological variables is ENSO, with variations on a 27 -year timescale. For example, linkages can clearly be seen between ENSO indices and gridded precipitation data sets. Such an analysis has been carried out by Becker et al. (2013) using global land-surface precipitation of the past 110 years at a spatial resolution of $0.5^{\circ}$ (Schneider et al., 2011). At this scale, the data are capable of resolving global and synopticscale precipitation patterns. Over this longer than centennial time period, the correlation of each grid cell against the negative Southern Oscillation Index (i.e. the occurrence of $\mathrm{La}$ Niña events) reveals that years with strong ENSO phases (such as the La Niña years 2010 and 2011) feature precipitation anomaly patterns in the same overall ENSO sensitive regions. Therefore, these predictable anomaly patterns point to regions where extreme precipitation events (Thailand; Queensland, Australia; El Salvador) or droughts (northern Mexico, southern US, southeastern Africa, Hong Kong) have also occurred (Fig. 2) during a specific year or period.
ENSO has been linked to floods in Peru (Waylen and Caviedes, 1986), the USA (Cayan et al., 1999; Jain and Lall, 2000, 2001; Pizaro and Lall, 2002, Sankarasubramanian and Lall, 2003), China (Lin et al., 2005; Zhang et al., 2007), Australia (Kiem et al., 2003) and generally to the extra tropics (Ward et al., 2010), as well as to precipitation anomalies in Europe (Bichet et al., 2014). PDO and the North Atlantic Oscillation (NAO) have been shown to influence precipitation and flood regimes and to lead to flood episodes of varying intensity in various regions (e.g. Cayan, 1996; Jain and Lall, 2000; Bouwer et al., 2006; Kingston et al., 2006; Maraun et al., 2010; Bichet et al., 2011; Rana et al., 2011; Gregersen et al., 2013). Moreover, Ward et al. (2010, 2014b) examine correlations between observed peak discharge and the Southern Oscillation index (SOI) at the global scale and show that peak discharges have a strong sensitivity to ENSO in catchments over large parts of the globe.

In Mediterranean Europe, most of the weather systems causing intense and/or persistent rainfall originate over the Atlantic Ocean and are carried towards the Mediterranean region by westerly winds. These systems can interact with regional topography and produce localized extreme precipitation (Rudari et al., 2005; Pinto et al., 2013), inducing severe river floods. In the upper troposphere over the Euro-Atlantic region, the westerly flow is characterized by two jets: the Atlantic jet, which crosses the ocean with a northeasterly trajectory, and the African jet, which flows above the coast 
of North Africa. The cross-jet circulation of the Atlantic jet favours storm activity in its exit region, while the cross-jet circulation of the African jet suppresses this kind of activity in its entrance region. It follows that the rainfall distribution downstream of these cross-jet circulations is strongly influenced by their relative positions (Gaetani et al., 2011; Toreti et al., 2010). Specifically, in autumn, rainfall is copious and more persistent in the western Mediterranean Basin when the Atlantic jet is relatively strong but its northeasterly tilt is small, and the African jet is in its easternmost position. In winter, rainfall is abundant in the eastern Mediterranean Basin; this is when the Atlantic jet reaches the Scandinavian Peninsula and the African jet is in its westernmost position. In spring, when the two jets weaken, the Atlantic jet retreats over the ocean, but the African jet stays in its winter position, and rainfall is more persistent and abundant in the Alpine region and in the Balkans. Therefore, the origin for many floods is not necessarily local, but is related to large-scale circulation patterns like ENSO or jet stream tracks.

These examples show that the investigation of global climate processes might help to understand and predict local floods. However, the potential benefit goes further. Linkages across different hazards and across large distances are possible, since the flood and drought potential for far catchments may be related. Specifically, one can hypothesize that persistent spatial patterns of surface temperature in the tropical oceans lead to enhanced probabilities of regions where strong convection takes place and provides a moisture source that could lead to floods in certain areas. The same anomalous surface temperature patterns could also lead to suppression of convection in other tropical areas, as well as to changes in the position and strength of the mid-latitude jet stream and the eddies that are coupled to it. The net result could be that persistent centres of low and high pressure are set up in the mid-latitudes, such that tropical moisture is funnelled repeatedly into the persistent low-pressure regions leading to floods, and droughts persist associated with the atmospheric blocks associated with the high-pressure centres. The net result may be synchronous flooding and drought patterns at seasonal to annual scales across the world. The potential dynamics of such a system at a global scale under a changing climate are discussed in Karamperidou et al. (2012, 2013).

\subsection{Stationary or time-varying random variables?}

Traditional flood frequency analysis assumes stationarity. This assumption implies that flood characteristics fluctuate around a constant value, and that flood quantiles can be determined from data collected over relatively short time periods, typically a few decades. It is assumed that the floodgenerating processes remain constant in time, and that flood probability represents the long-term natural variability of the climate-catchment system. Changes in flood characteristics are expected to result from anthropogenic interventions in this system, such as human-induced climate change, land-use change or river training.

Stationarity implies that each flood record has the same probability of occurrence at any time. However, Sects. 2.1 and 2.2 suggest that there may be periods with distinct flood peak distributions for catchments with strong climate-flood links. Analyses of long-observation data and historical flood records give evidence that floods tend to cluster in time in many regions, and hence that the traditional assumption of time-invariant probability distribution does not hold. Periods with higher or more frequent floods can be differentiated from periods with minor flood activity (e.g. Jacobeit et al., 2003; Schmocker-Fackel and Naef, 2010; for a compilation of European studies, see Hall et al., 2014). This is attributed to low-frequency climate variability, as climate has wellorganized modes of interannual, interdecadal and lowerfrequency variability modulating atmospheric moisture uptake, transport and deposition (precipitation) processes, and hence flood conditions (Hirschboeck, 1988). Knox (2000) studied the effect of climate variability on flood probability at the Mississippi River. He divided the 120-year-long observation period into four decadal-scale sub-periods according to their prevailing global circulation patterns and calculated flood quantiles for each sub-period separately. The 50-year flood was approximately $50 \%$ larger during episodes with more frequent meridional circulation patterns than in periods with more common zonal circulation patterns. This approach of stratifying the flood sample into sub-samples with different climate modes has been repeated, for example, by Kiem et al. (2003) for 40 flood gauges in New South Wales, Australia. The stratification of a regional flood index according to ENSO and the Interdecadal Pacific Oscillation (IPO) leads to very marked differences in flood quantiles. In flood frequency estimation, such variations will show up as a bias as well as an underestimation of the uncertainty of projecting future flood hazards because the interdecadal and longer oscillations are ignored.

Consequently, even in the absence of human-induced changes, the statistical properties of flood time series may vary significantly over time. Flood characteristics may not be fixed, but may float dynamically in time. These regimelike patterns with quasi-cyclic behaviour of flood-rich and flood-poor periods need to be understood, and those regions and conditions under which marked regimes exist need to be identified.

An interesting research question is whether flood regimes occur in accordance across large distances. If the flood behaviour of large regions responds in a similar way to largescale or global climate regimes, this should be seen in concurrent flood-rich clusters and flood-poor periods. For instance, Schmocker-Fackel and Naef (2010) find that large floods tend to synchronously occur in different regions of Europe since 1500 (e.g. in Switzerland and the Czech Republic). Willems (2013) identifies north-south patterns of multidecadal oscillations in rainfall extremes across Europe for 

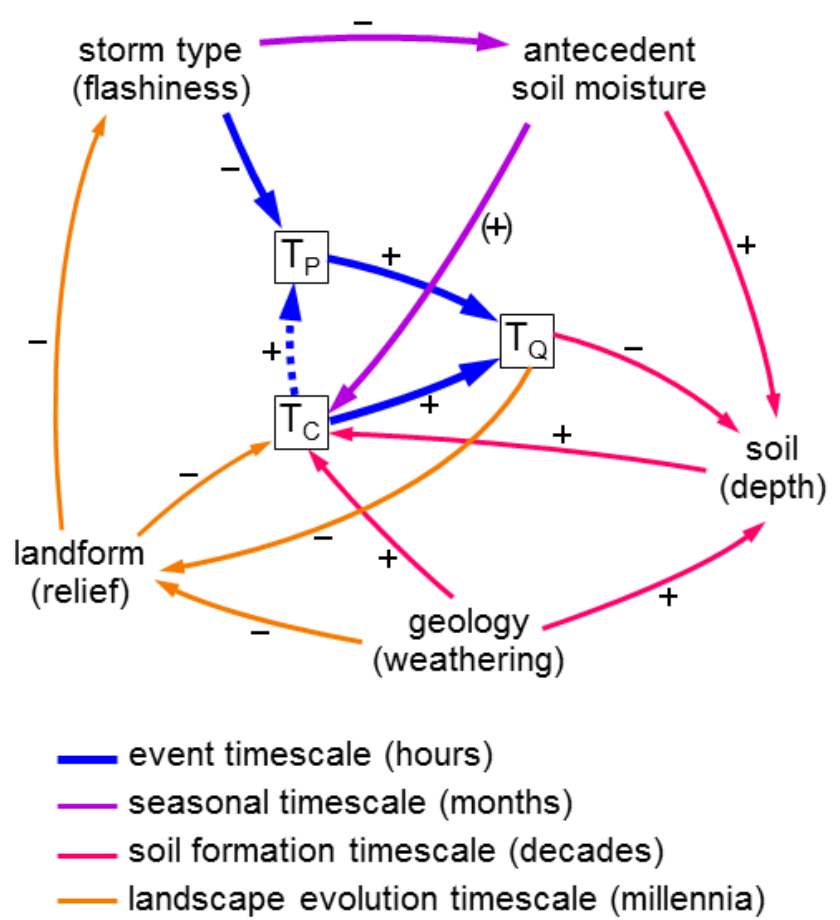

Figure 3. Schematic of the coupling of process controls on the flood timescale. Plus and minus signs indicate whether coupling is positive or negative, i.e. whether an increase in a variable increases or decreases another variable. $T_{\mathrm{P}}$ : precipitation timescale, characteristic duration of rainfall producing a maximum annual flood; $T_{\mathrm{C}}$ : catchment response timescale, time delay of catchment routing; $T_{Q}$ : flood timescale, characteristic flood duration (from Gaál et al., 2012).

the past 100 years and explains them by persistence in atmospheric circulation patterns over the North Atlantic during periods of 10 to 15 years. In the late 19th century, central Europe was particularly affected by recurring large and destructive floods (e.g. Pfister, 1999; Mudelsee et al., 2006; Brazdil et al., 2005; Schmocker-Fackel and Naef, 2010). Using an atmospheric general circulation model (GCM), Bichet et al. (2014) found that this 15-year period of destructive floods in central Europe was induced by a change in the atmospheric circulation (positive PNA-like - Pacific-North American pattern and negative summer NAO pattern), itself driven by changes in the tropical SSTs (eastern tropical Pacific and Indian Ocean sea surface temperatures). Although the impact of tropical SSTs on European precipitation has previously been documented in the literature (e.g. Bronnimann, 2007), there is still no clear understanding of how and under which circumstances the SST signal transmitted from the tropics to Europe can lead to precipitation extremes associated with flooding. Although other parts of the world were also affected by above-average precipitation in the late 19th century (Gergis and Ashcroft, 2012), the reasons why this period was so exceptional in Europe are still unclear.

\subsection{Recent or long term?}

Traditionally, understanding of flood characteristics and flood frequency analysis have been focused on data from the most recent decades, based on the idea that flood characteristics result from current catchment characteristics. From a long-term perspective, it must be recognized that flood characteristics are the result of an interplay of climate, geology, topography, vegetation (biology) and humans. As an example, consider the way precipitation and catchment timescales are related to flood timescales. Figure 3 (from Gaál et al., 2012) illustrates some of the factors that influence these three timescales. Note that Fig. 3 could be extended by feedbacks in the climate system and the role of humans as strong floods may lead people to build flood control systems that modify hydrology (Di Baldassarre et al., 2013). The timescales shown in Fig. 3 are not independent, and the interplay amongst them can be interpreted differently at different timescales, from hours to millennia. The events that produce the maximum annual floods are those for which the storm duration is close to the concentration time of the catchment, because the catchment-response timescales filter the distribution of all storms to produce the distribution of floodproducing storms (Viglione and Blöschl, 2009). This is the reasoning behind the rational method for flood estimation and it applies at the event scale (e.g. Pilgrim and Cordery, 1993, p. 9.13). At the seasonal timescale, flood characteristics tend to be closely related to the seasonal water balance, and, conversely, runoff event types affect the seasonal water balance through rainfall and snowmelt (Sivapalan et al., 2005). At the timescale of decades, however, the flow paths as well as soil moisture affect erosion during floods and soil evolution (modulated by differences in geology), while soil depth and permeability affect flow paths and therefore the flood response at the event scale. At the landscape evolution timescale there are further interactions (Abrahams and Ponczynski, 1984; Tucker and Bras, 2000). To fully understand floods, this long-term interplay has to be disentangled. Because of the coupling between different processes across many spatial and temporal scales, the interplay between climate and catchments needs to be seen as a complex system (Rihani, 2002; Raupach, 2005; Kumar, 2007; Blöschl and Merz, 2010), i.e. systems with a large number of strongly interdependent variables at multiple space- and timescales.

One promising avenue to better understand this long-term interplay and the role of climate for flood characteristics is the use of historical and geological archives (e.g. Kochel and Baker, 1982; Baker, 2008; Glaser et al., 2010; Gilli et al., 2012). Historical archives provide exact dates of catastrophic floods, often together with detailed descriptions of the hydro-meteorological conditions and the resulting damage. However, these archives are limited to regions that were populated over a long period and only reach back a couple of centuries. Millennial-scale variations from potentially all regions worldwide can be revealed from river and lake 


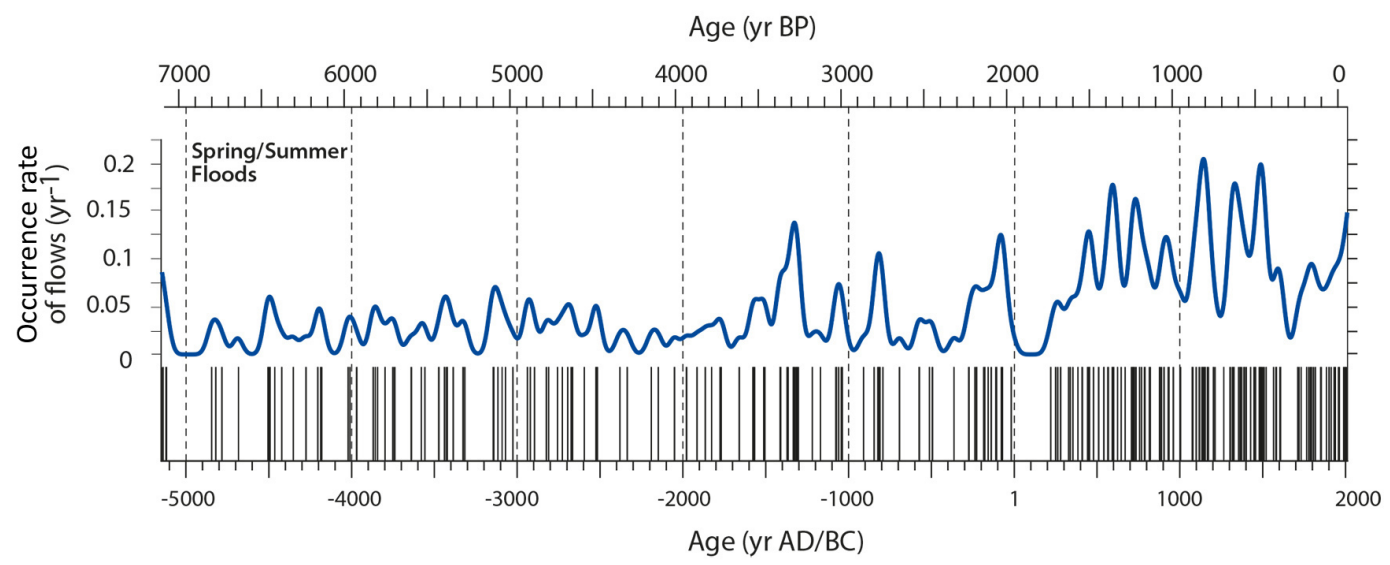

Figure 4. A 7000-year reconstruction of flood events from Mondsee, Upper Austria. Lower panel: occurrence of flood events. Upper panel: occurrence rate calculated by using a Gaussian kernel regression with a 30-year bandwidth (data from Swierczynski et al., 2013).

sediment records (e.g. Benito et al., 2003a, b; Swierczynski et al., 2012, 2013; Wilhelm et al., 2012, 2013). While river sediments typically reflect periods of both accumulation and erosion and thus mainly reflect highest-amplitude floods, lakes represent ideal natural traps which continuously collect suspended detrital sediments transported by floods. In the case of annually laminated sediments, even the seasons of palaeofloods can be precisely determined by the microstratigraphic position of a detrital layer within the annual succession of lake deposition (Mangili et al., 2005; Czymzik et al., 2010).

Figure 4 shows exemplarily the reconstruction of spring and summer floods from laminated sediments of Mondsee, Austria. The amount of temporal variability in the occurrence of floods is striking. There is a period of more than 200 years (21 BC-AD 216) without any flood documented, whereas the average frequency is 0.04 floods year ${ }^{-1}$, yielding nine floods for such a time interval. Similar fluctuations are seen in other palaeoflood records (e.g. Ely et al., 1993; Knox, 2000; Benito et al., 2003a, b).

Combining flood reconstructions with climate reconstructions provides a great potential to better understand climateflood linkages. However, interpreting sedimentary palaeoflood records requires the precise timing of detrital flood layer deposition and a detailed understanding of the mechanisms from the sediment source to the sink. The entire chain of processes needs to be captured, from the hydrometeorological event and the resulting erosion in the catchment to sediment transport into the lake and distribution of suspended material within the lake basin. This in turn requires both detailed investigation of the lacustrine sediment formation including the influence of land-use and vegetation changes on catchment erosion and sedimentation, and calibration of flood layer deposits with meteorological and hydrological observations. Such a detailed understanding allows for an assessment of the completeness of the palaeoflood record and whether certain flood types are missing.

Where very long flood time series extending over millennia can be reconstructed with sufficient reliability, they provide a data-based approach to separate the impact of anthropogenic climate change on floods from natural climate variability. Given the large uncertainty of today's models to simulate floods under changing climate, reliable palaeoflood reconstructions have an exciting potential to determine the natural variability of the flood activity, to better constrain flood projections under climate change, and to better assess flood recurrence times and flood-climate relations for various climate states and timescales.

This long-term view has been successfully used for flood management in dam safety considerations by defining upper limits of flooding through palaeoflood and documentary studies (Enzel et al., 1993; Levish, 2002). However, the systematic integration of palaeo- and historical records into flood frequency analysis has been limited. An argument that is often raised is that if climate is now changing, the long-term record is of little benefit because the past is no longer the key to the present. However, even with a changing climate, from a meteorological/mechanistic perspective, the laws of physics which result in rain, snow and floods are time-invariant. Non-stationarity is produced by changes of these processes in their frequency, magnitude, location, persistence, intensity and clustering. These are driven by the interplay described earlier and are partially deterministic (Sect. 2.1). Hence the extreme events of the past are indeed important indicators of what the atmosphere-catchment system is capable of, given the right interplay of factors. They have left evidence in the landscape of the occurrence of a real event (not something emerging from modelling). Floods - by their very nature - are rare events; hence there is a need to identify them in all temporal contexts (palaeo, historical and 
systematically gauged) and explain them from a mechanistic understanding of causal drivers.

\section{Exploiting climate-flood linkages to better manage flood risk}

How can a better understanding of climate-flood linkages be used for improved flood risk management? In the following we contrast the traditional approaches for flood estimation, flood projections under climate change, and for flood management with emerging perspectives based on this improved understanding of floods in their climatic context.

\subsection{Flood estimation: process-neutral or process-based?}

Flood estimation does not traditionally differentiate between flood event types and flood generation processes and can be termed process-neutral. The main approach to estimate flood probabilities is based on extreme value statistics, i.e. fitting distribution functions to ordered sequences of observed flood peaks, ignoring the underlying processes and extrapolating the tails of the distribution to low exceedance probabilities. It is typically assumed that the flood data used are independent and identically distributed. This has been popular largely because most common statistical methods for the analysis of extreme values make this assumption. Consequently, even in locations where a mix of mechanisms such as frontal storms, localized thunderstorms and rain-on-snow events, which have very different space and time attributes, leads to floods, most analyses focus on finding a single best distribution to fit them instead of identifying and modelling the mixtures. Flood heterogeneity has been shown to invalidate the iid assumption in different catchments (e.g. Murphy, 2001; Todhunter, 2012). Further, flood clustering may introduce serial correlation in the time series and may invalidate the independence assumption.

Even more disturbing is the possibility that climate-related fluctuations may significantly bias flood quantile estimates. Franks and Kuczera (2002) point to the need to distinguish between conditional and unconditional flood probability. The unconditional, long-term probability averages across different climate states, whereas the conditional probability depends on the current climate state. Traditional flood frequency analysis results in sound estimates of unconditional flood probability only if the observed data accurately represent the different climate states. Moreover, it may seriously over- or underestimate flood probability in a given year. In a comparison of unconditional and conditional flood probability, Kwon et al. (2008) found that the conditional 100-year flood fell outside the confidence interval of the unconditional estimate. Jain and Lall (2001) explore how the long-term, ENSO-related climate variability impacts the exceedances of flood thresholds. From their bootstrap analysis they conclude that there is a much higher chance of obtaining substantially different numbers of exceedances of the design flood derived from the iid assumption. Hence, low-frequency fluctuations may lead to fat tails of flood distributions and may increase the potential for surprise.

The contrasting, process-based perspective is founded on the premise that flood events of different types occur in a given catchment, and that flood characteristics are linked to the hydro-meteorological processes driving the water input into catchments, to the runoff generation processes, and to the flood-routing processes. The expectation is that processbased approaches can provide information on flood probability estimation and allow for more reliable and catchmentspecific characterization of the flood hazard.

The analysis of flood events in terms of their meteorological causes is an important starting point for understanding how flood-climate linkages can influence flood probability distribution functions (Hirschboeck, 1988). Different storm types can trigger completely different flood processes in the same catchment. For example, in the southwestern United States (Fig. 5), intense summer convective thunderstorm cells interact selectively with a watershed's drainage network and topography, typically generating flashy flood hydrographs. In contrast, synoptic-scale winter storms deliver snow and rain to large areas and tend to generate flood hydrographs characterized by sustained and cumulative flows. Catchments with flood peaks generated by a mix of climatic mechanisms may exhibit complex heterogeneous frequency distributions, but stratifying the flood record according to climatic cause (Fig. 5) reveals useful information about the individual processes that shape the catchment's overall flood frequency distribution. If marked climate-flood linkages can be identified, it allows for flood estimation and design to be improved. Kwon et al. (2008) stress the reduction in uncertainty of the 100 -year estimate when they include climate information. This reduction can be used to decrease the costs of over- or underdesign. However, in order to benefit, there is a need for more statistical and theoretical analysis of temporal variability in extremes in order to understand how temporal clustering or existence of a range of stochastic processes or mixture of distributions affect the tails of flood distributions.

The reasoning that better process understanding improves flood estimation can be extended further along the chain of flood processes. Runoff able to generate floods is produced in three main ways: (1) at the surface by infiltration excess (Hortonian overland flow) due to low or no infiltration intensities of the soil or surface, (2) by saturation excess (saturation overland flow) due to saturating the porous soil matrix, or (3) by fast subsurface flow, usually triggered by a variety of mechanism and conditions (Bachmair and Weiler, 2011). Based on the specific setting of a given catchment (geology, soils, topography, vegetation cover, land use, etc.), the three processes interact differently; therefore in conjunction with the hydro-meteorological conditions, different runoff generation processes can dominate the flood generation (Weiler et 

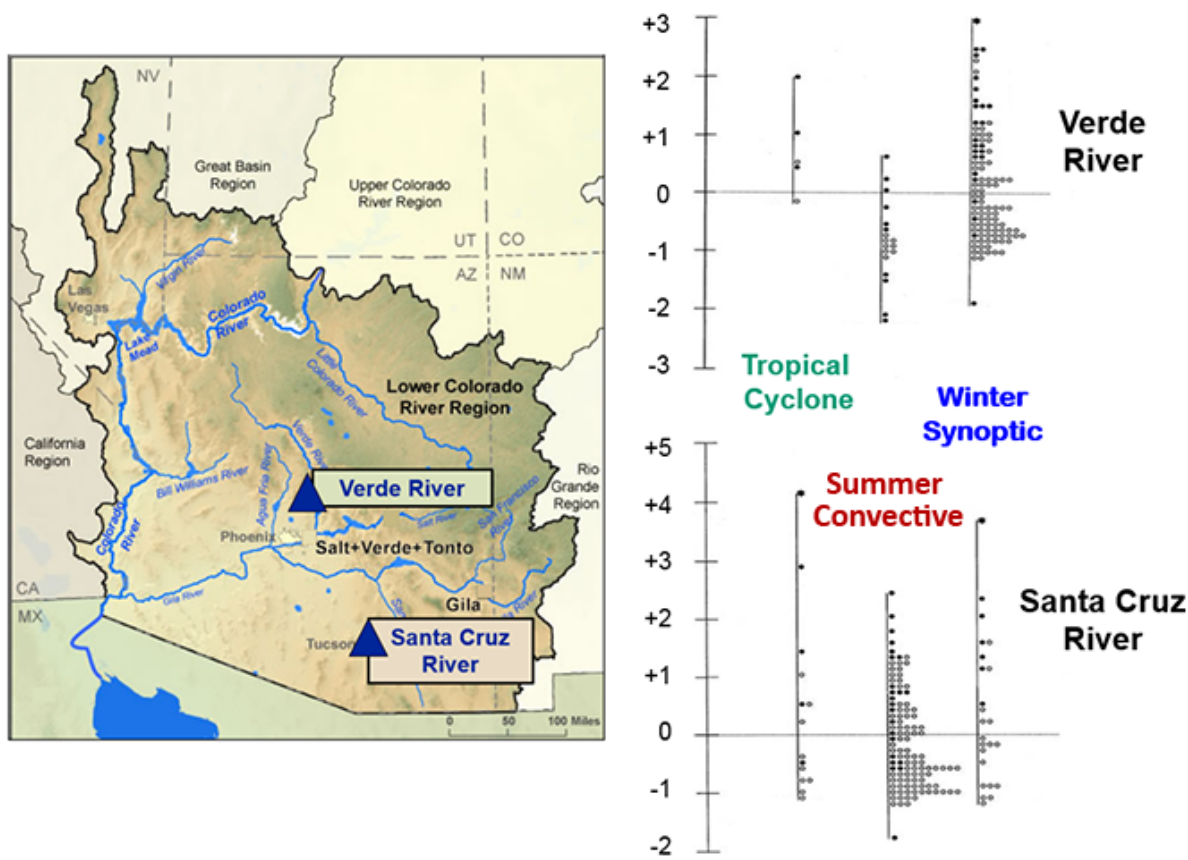

Figure 5. Stratification of flood events according to climatic mechanism. Climate-based flood heterogeneity is evident in two Arizona watersheds when observed flood peak distributions are stratified according to the three dominant flood-producing mechanisms in the southwestern United States. Shown are histograms of instantaneous peaks above base, plotted as standardized dimensionless $z$ scores for comparison. The Santa Cruz River at Tucson floods most frequently in response to summer convective thunderstorm rainfall, but the two largest peaks of record were produced by tropical-cyclone-enhanced rainfall and precipitation from winter synoptic storms, respectively. In contrast, in the Verde River below Tangle Creek, some $300 \mathrm{~km}$ to the north, the most frequent and largest floods are produced by winter precipitation events (based on House and Hirschboeck, 1997).

al., 2009; Steinbrich and Weiler, 2012). Rogger et al. (2012) give the following example, which illustrates the benefits of understanding the dominant controls on flood probability. Empirical distribution functions of flood peaks in small catchments sometimes show abrupt changes in the slope; that is, the largest flood peaks are significantly larger than the rest of the record. For Austrian Alpine catchments, Rogger et al. (2012) suggest that these abrupt changes are the consequence of a threshold of storage capacity being exceeded, which causes fast surface runoff in large parts of the catchments. This effect is not captured by flood frequency statistics, which tend to underestimate floods in these catchments.

Another example of the effect of runoff processes on the flood distribution function is shown in Fig. 6. The left graphs show the flood frequency curve and the associated event runoff coefficients for the Weißach catchment at Zwing located in western Austria (Merz and Blöschl, 2008a). Owing to orographic enhancement of northwesterly airflows, rainfall is high and persistent and runoff coefficients tend to be constantly high. As rainfall becomes more extreme, runoff coefficients only increase moderately as they are already close to unity, and the flood frequency curve of the catchment shows a downward curvature. Assuming that the rainfall regime remains similar, and on the basis of the runoff coefficients, one would expect that the trend continues as one extrapolates to higher return periods. In contrast, runoff coefficients of Wulka at Schützen in the dryer eastern part of Austria are much lower and increase with increasing return periods. The flood frequency curve shows an upward curvature, and, on the basis of the analysis of the runoff coefficients, one would expect that this trend continues, assuming the rainfall regime remains similar. Hence, the information on runoff coefficients gives more confidence in extrapolating to higher return periods.

The idea that the flood frequency curve is a fingerprint of important processes can finally be extended to flood routing and river-floodplain interactions. Changes in the slope of the flood frequency curve may also result from threshold processes in the river system: for example, when the river banks are inundated and large additional storage capacity is activated. Apel et al. (2009) show for the Lower Rhine in Germany that dike breaches lead to significant retention effects by pruning the flood waves, which in turn modify the flood frequency curve downstream of breach locations. This effect only occurs beyond a certain (extreme) threshold, and it is typically not contained in observed time series. Hence, a process-neutral, purely statistical approach, i.e. not including this specific process in the extrapolation to extreme floods, results in significant overestimation of large flood quantiles. 

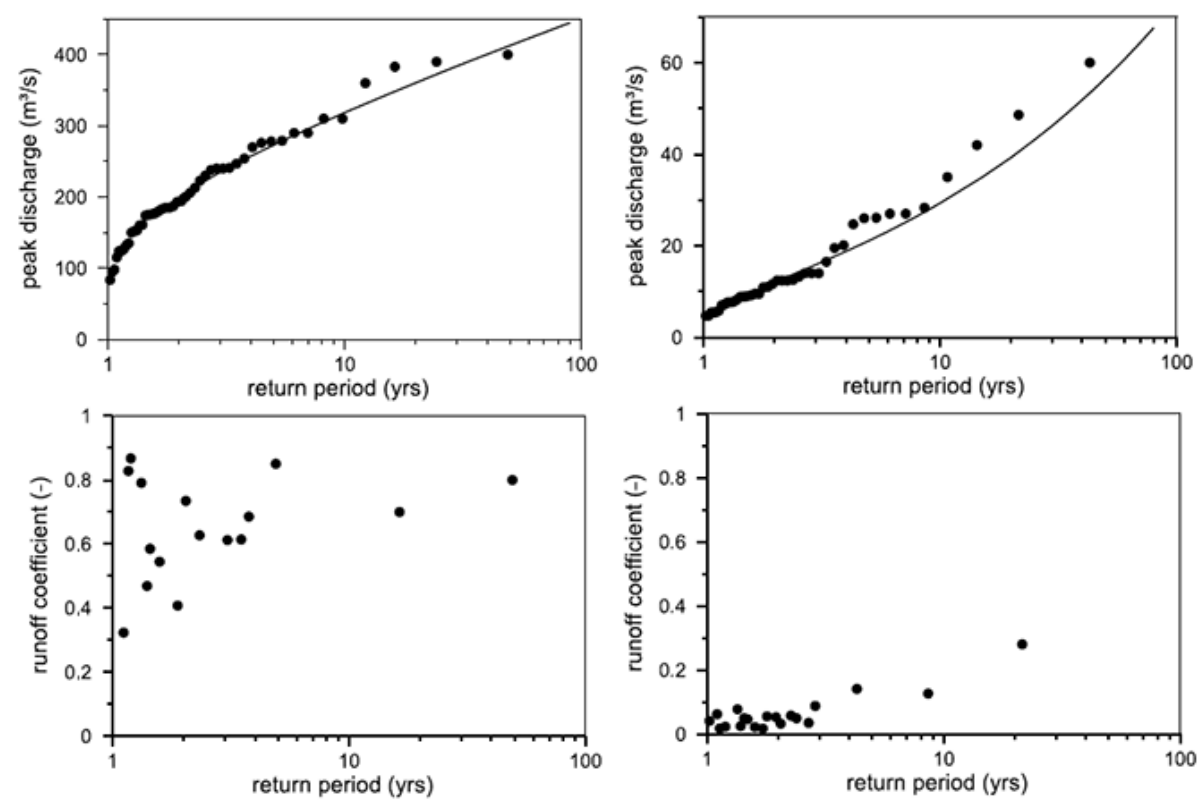

Figure 6. Flood frequency plots (top panels) and runoff coefficients (bottom panels) of the associated flood events for Weißach at Zwing $\left(199 \mathrm{~km}^{2}\right)$ (left panels) and Wulka at Schützen $\left(383 \mathrm{~km}^{2}\right)$ (right panels) (from Merz and Blöschl, 2008a).

We support the reasoning of Merz and Blöschl (2008a, b), who argue that much better use should be made of the wealth of knowledge on hydrological processes in estimating flood probabilities, and have introduced the concept of flood frequency hydrology. It is based on a systematic expansion of information on flood processes beyond the flood sample at the site of interest in order to derive more informed estimates of flood frequencies. By combining local flood data statistics with additional temporal information on historic floods, spatial information on floods in neighbouring catchments and causal information on the flood processes, the subtleties of the flood characteristics at the site of interest can be more fully captured and the uncertainty of the flood quantile estimation reduced. It is important to note that the complete spectrum of processes - in the atmosphere, catchment, river system and floodplains - should be included in a process-based flood estimation. This is a very broad definition of flood frequency hydrology and subsumes, for example, elements of the flood hydro-climatology concept of Hirschboeck (1988).

These process-based approaches also have their downsides. For example, they require a detailed understanding of the flood-generating processes in a catchment. Furthermore, the stratification of flood events into different flood types increases the sampling uncertainty of the frequency analysis. Nevertheless, the small sample of floods produced in a catchment by an infrequently occurring process provides some of the best information we have in the observed record on what future flooding from that same process might be like. Hence, we conclude that the past dominance of processneutral, purely statistical approaches to the flood estimation problem should be augmented with a broader approach: the development of process-based methods to complement standard approaches to flood estimation, in particular for assessing extreme floods. There is a need for innovative statistical extreme value methods (e.g. as discussed in Serinaldi and Kilsby, 2014) and process-based approaches, and for merging them into tools that can be used by practitioners.

\subsection{Climate change: model chain versus model-chain- augmented?}

Anthropogenic climate change is perceived as particularly relevant by authorities responsible for flood design and management. Therefore, in this section the benefit of understanding climate-flood linkages for projections of future floods under climate change is elaborated.

The typical approach for deriving future flood hazard scenarios under climate change is to implement model chains consisting of the following elements: "emission scenario $\rightarrow$ general circulation model $(\mathrm{GCM}) \rightarrow$ downscaling, possibly including bias correction $\rightarrow$ hydrological catchment model $\rightarrow$ flood frequency analysis" (e.g. Dankers and Feyen, 2009; Kay et al., 2009; Ott et al., 2013), with the emission scenarios stemming from scenarios of future economic and social development (Nakicenovic and Swart, 2000). The IPCC has changed the climate change impact modelling concept slightly with the introduction of the concept of representative concentration pathways (Moss et al., 2008), but this will not affect the above-mentioned modelling chain except for replacing the initial element from "emission scenario" to "representative concentration pathways" (Moss et al., 2010). 
In either case the natural variability in the general circulation models is produced without a link to the observed timing of variability mode stages. The "pure" climate change signal can thus be analysed in ensembles of model simulations. Multi-model ensembles can reduce the uncertainties associated with deviations of individual model climatologies. However, uncertainty is still large in projected flood changes, and the IPCC SREX report (2012, p. 178) states that "overall there is low confidence in projections of changes in fluvial floods". One of the main uncertainty sources is the problem all GCMs have in simulating regional and local rainfall. Causes for these shortcomings are influences of local orography and land surface that are not resolved and smallscale processes which cannot be represented by a GCM. Under such conditions, it is not recommendable to infer future changes in flooding directly from the GCM-produced rainfall at individual grid points. This constraint will ease as climate models are applied at higher resolutions - for example, in the work by Kendon et al. (2014) using a regional climate model at up to $1.5 \mathrm{~km}$ resolution to resolve convective rainfall in the UK.

Statistical downscaling can be used to estimate the local rainfall from large-scale parameters. It can, for example, be based on the relationship between extreme rainfall and large-scale atmospheric circulation patterns (ArnbjergNielsen et al., 2013). Circulation patterns or weather types, either subjectively (e.g. Hess and Brezowsky, 1952) or objectively (e.g. Philipp et al., 2007) derived, can take different atmospheric variables into account (e.g. direction of flow, atmospheric humidity, temperature). Climate change signals in the relevant weather types, in particular in the frequency of occurrence and persistence, can then be identified for the individual climate change simulations. Instead of (or in addition to) using weather types, it is also possible to identify cyclone tracks which are associated with extreme precipitation and enhanced flood risk in specific regions. A wellknown example of a pathway associated with major flooding in central Europe during summer is van Bebber's $\mathrm{Vb}$ track (e.g. Kundzewicz et al., 2005).

Where a strong climate-flood link can be identified for a given catchment, this link can be used to directly project future flood changes. For river gauges in the Mekong Basin, Delgado et al. (2012) identify a statistical relationship between flood variance and the western Pacific monsoon variance. A non-stationary flood frequency model is developed in which the monsoon variance drives temporal changes in flood quantiles (Delgado et al., 2014). For climate change scenarios, the variance of the monsoon is extracted from GCM runs. The simplicity of the monsoon-flood link allows for the derivation of large ensembles of flood projections under climate change almost immediately when GCM output is available. Such approaches are promising - and complement the above-mentioned climate change model chains - because they bypass precipitation, which is poorly simulated by global and regional climate models. Rather than using precipitation, they are based on circulation-linked atmospheric variables, such as large-scale pressure fields and wind velocities, which are frequently much better represented by climate models. Problems with this approach, as in all statistical downscaling procedures, occur when there is non-stationarity in the link between the scales and parameters, a lack of data for estimating them, or a need for extrapolation to situations far from the area for which the statistical link has been derived. However, we see a great potential in such low-dimensionality models for understanding flood changes because they force the modeller to identify the dominant processes and they offer the possibility for establishing direct causality links for observed and projected flood changes (Hall et al., 2014).

Notwithstanding the approach that is selected, one has to be aware of the current limitations of global and regional climate models, which go beyond errors in simulating precipitation. For example, SSTs are one of the most important drivers for precipitation on decadal timescales (e.g. Bichet et al., 2011). The spatial patterns of SSTs are particularly relevant in driving regional precipitation. This is an issue of concern, considering that coupled atmosphere-ocean GCMs from the Coupled Model Intercomparison Project Phase 3 (CMIP3) and 5 (CMIP5) globally predict warming of SSTs that is too uniform (e.g. Shin and Sardeshmukh, 2011).

Another approach with great potential beyond the typical use of model chains is the development of processbased scenarios of flood response to realistic shifts in climate. For instance, in the southwestern US, where different flood-generating storm types dominate in different seasons (Fig. 5), the circulation features associated with each storm type are distinctly different. This information can be used to design alternative scenarios for a catchment's flood response to climate change. A poleward shift in the latitude of the current winter storm track, an increase or decrease in the magnitude or frequency of eastern North Pacific tropical cyclones, or an expansion of the low-latitude tropical moisture belt that enhances the summer thunderstorm season would each have a profound impact on the overall probability distribution of flood peaks in southwestern US watersheds. Catchmentbased future flooding situations constructed by sampling observed floods within each of these flood types could be used to develop alternative planning scenarios for different regional atmospheric circulation responses to changing global climate drivers based on GCM output or projected circulation regime shifts (Fig. 7).

Such scenarios could be derived via simulation or via data analysis: for example, relying on historical periods with analogous conditions in the same catchment. Alternatively, one could derive possible future flood changes by investigating catchments which have a climatic regime that is similar to the regime we expect in the future in a specific catchment. Such process-based scenario approaches do not need to be based on the relation between floods and atmospheric moisture transport or storm tracks. They can be applied more 


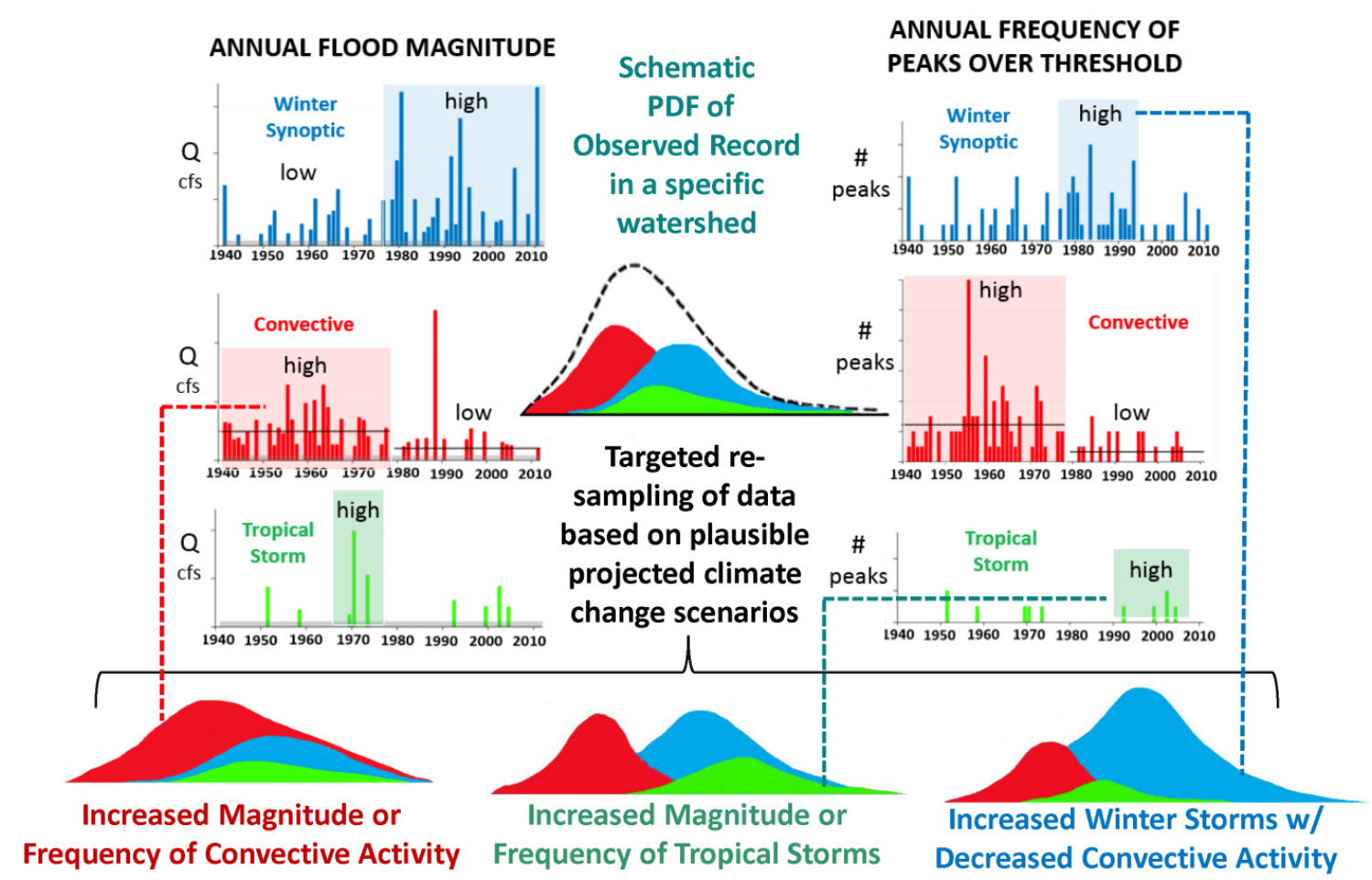

Figure 7. Schematic illustration of a proposed method for the development of process-based flooding scenarios by re-sampling distinctive segments of the observed flood record. Extreme flooding variability often occurs as clusters or episodes of high or low magnitudes of annual flood maxima (left-hand side of figure), and/or high or low frequencies of flood peaks that exceed a defined threshold (right-hand side of figure). To use these modes of variability in scenario development, the flood record can be partitioned into separate time series for each atmospheric-circulation-linked flood-generating process (i.e. winter synoptic, convective, or tropical storm) and then analysed using subjective and objective methods (e.g. change-point analysis) to identify statistically significant and climatically unique episodes of extreme flooding behaviour (shaded segments of flood time series). The magnitude and frequency attributes of the flood peaks in each unique episode can then be iteratively sampled and recombined to simulate new modes of flood-generating behaviour during plausible projected climatic shifts (e.g. increased magnitude and frequency of winter synoptic storms combined with decreased frequency of convective activity).

directly to surface hydro-meteorological variables. For example, in several European regions, human-induced climate change is associated with an increase in winter precipitation and a higher snow line. Although we may not be very confident about the actual future precipitation, we can be confident about the general trend of increasing winter precipitation and decreasing fraction of snowfall. Indeed watersheds in mountainous areas of the western United States that rely on seasonal snowpacks are already vulnerable to shifts in the timing of runoff and increases in early spring flooding because warmer temperatures promote an earlier snowmelt season and more precipitation falling as rain instead of snow.

Such process-based scenarios might provide a space possible future flood characteristics, conditioned on our current knowledge. This possibility space of flooding characteristics in a given catchment could be compared to the vulnerability of the elements at risk, separating catchments which require special attention from those which are less vulnerable to the conceivable changes in climate. Prudhomme et al. (2010) introduced the closely related "scenario-neutral approach to climate change impact studies", which is based on sensitivity analyses of catchment response to a plausible range of climate changes. An advantage of this approach and related ideas, such as what-if analysis or cause-and-effect analysis, is that it is much easier to understand and interpret changes in flood behaviour. However, the complexity of the typical climate model chains impedes the understanding of how changes in climate propagate to changes in flood characteristics. Hence, in parallel to improving climate model chains and their reliability for flood projections under climate change, a better understanding of climate-flood linkages has a large potential for flooding under climate change.

Currently, human-induced climate change and natural climate variability are not operationally incorporated into flood management practice, in part because floodplain managers are constrained by the absence of accepted alternatives to standard stochastic methods. To overcome this impasse, there is a need for methods that can incorporate realistic, processbased climate change scenarios into the statistics of gauge records in ways that demonstrate an improvement on the traditional flood frequency analysis approach. Probabilistic methods now being used with palaeoflood data present one 
Table 2. Average economic flood losses in Australia stratified according to ENSO phase. Analysis based on data from EM-DAT (CRED, Belgium) for 1971-2010, and insured loss data normalized for changes in wealth from the Insurance Council of Australia for 1967-2010 (for method, see Crompton et al., 2008). The $t$ test and Mann-Whitney $U$ test (MWU test) were applied indicating the significance of the differences in average losses.

\begin{tabular}{lccccc}
\hline \multirow{2}{*}{ Data set } & $N$ & \multicolumn{2}{c}{ Average damage } & \multirow{2}{*}{$t$ test } & \multirow{2}{*}{ MWU test } \\
\cline { 2 - 4 } & & La Niña & Non-La Niña & & \\
\hline EM-DAT [USD] & 57 & 1070 & 142 & $p=0.026$ & $p=0.014$ \\
Insurance Council of & 50 & 369 & 61 & $p=0.014$ & $p=0.024$ \\
Australia [AUD] & & & & & \\
\hline
\end{tabular}

approach, but they are not directed toward future climate change and are limited by the availability of palaeoflood indicators in the landscape. Methods are needed that can augment existing flood peak records in ways that reflect how the climatic drivers of local hydro-meteorological processes have changed and will change in the past, present and future.

\subsection{Flood risk management}

What is the benefit of an improved understanding of climateflood linkages for flood risk management? In the last two decades, flood change research has been dominated by studies looking at changes in flood hazard, for instance due to human-induced climate change (e.g. Feyen et al., 2012; Ott et al., 2013, Ward et al., 2014a), land-use change or river training (e.g. Bronstert et al., 2007). Today it is recognized that all risk elements are dynamic through time, not only hazard (IPCC, 2012; Jongman et al., 2012).

Bubeck et al. (2012) show that societal responses are critical in understanding how vulnerability to floods changes over time. This study surveyed 752 households along the Rhine in Germany that experienced floods, with two major floods in 1993 and 1995. The results indicate that flood damage mitigation measures were implemented by households gradually over time, with major flood events being important triggers for accelerated implementation. Especially in the aftermath of the severe flood in 1993, a remarkable increase in the number of measures undertaken was observed. Kuhlicke et al. (2011) analyse the social vulnerability of households to floods for three European case studies. Using the definition of Blaikie et al. (1994), who understand vulnerability as “... the characteristics of a person or group in terms of their capacity to anticipate, cope with, resist, and recover from the impact of a natural hazard", they find that social vulnerability to floods is not a static characteristic. It is highly dynamic and may change even in the course of one single flood event. A household may be vulnerable in certain event phases - anticipation, resistance and coping, recovery and reconstruction and not vulnerable in others.

Further, a single driver may influence different risk components. For example, the societal perception of flood risk may be strongly influenced by a damaging flood, which may trigger investments in structural flood defence, such as flood retention basins, and may change flood hazard. In parallel, it may change exposure by flood-affected companies and private households migrating out of heavily flooded areas, and vulnerability by triggering private precaution in the flooded areas (Petrow et al., 2006; Kreibich et al., 2011). In addition, spatio-temporal interdependencies between vulnerability, exposure and hazard have to be expected. Current risk assessments, if they include dynamics at all, often examine dynamics in one of the components, whereas the interdependencies could be crucial (Di Baldassarre et al., 2013). For example, flood protection by dikes aimed at reducing the flood hazard can lead to increased development behind dikes, thus increasing exposure, the so-called levee effect (Tobin, 1995). In areas with high protection standards by dikes, individuals and societies may have low risk perceptions, and thus be less prepared for floods; in other words, they may have high vulnerability (Bubeck et al., 2012; Zaalberg and Midden, 2013). Spatio-temporal changes in all of these factors influence the overall flood risk.

Another factor that has received little attention in flood risk studies is the role of climate variability. As discussed earlier, many studies have found linkages between climate variability and extreme streamflow. A number of studies are now taking the step of examining whether such linkages can be detected between climate variability and flood losses. A preliminary analysis of recorded economic flood costs in Australia shows these to be sensitive to climate variability. Table 2 illustrates that average flood damages in Australia are significantly higher in La Niña years than in non-La Niña years. This signal appears to be robust to the loss data used, with significant differences for both loss data sets (EM-DAT, CRED, Belgium, and data on insured losses from the Insurance Council of Australia).

The work of Ward et al. (2010, 2014b) on relationships between ENSO and river flooding at the global scale is currently extended to assess the impacts of ENSO on risk (rather than discharge). Using the global flood risk modelling framework described in Ward et al. (2013), preliminary results presented at the EGU topical meeting in Potsdam show that there are clear and significant regional patterns of ENSO influence on disaster risk, in terms of both affected population 
and economic damage. Hence, socio-economic risks may to some extent be linked to climate regimes, which could have major implications for the insurance and re-insurance industry. For example, clustering of flood events increases the likelihood of a high number of damage claims within a short period of time - an issue which is aggravated if clustering is spatially coherent and damaging events occur at different locations within a short time interval.

Figure 8 illustrates the concept of dynamic flood risk and dynamic risk management, based on the climate-informed risk management approach of Pizarro et al. (2009). Since all components of risk vary in time, flood risk itself is dynamic. Some aspects of flood risk dynamics may be predictable, many others not. For example, changing climatic boundary conditions at interannual to decadal to century scales may be due to structured natural variability or anthropogenic factors or their interaction. Some of these changes may be smooth and potentially predictable over a certain timescale, while others (e.g. a reversal of the Atlantic Gulf Stream) may be abrupt and can be anticipated but not predicted. Given the fact that ENSO events are predictable to some extent across seasons (Cheng et al., 2011), it appears worth testing the predictive skill for seasonal flood forecasts in those regions where Ward et al. (2014b) have shown a strong sensitivity of peak discharges to ENSO. Drivers other than climate may be predictable to some extent as well. For example, exposition in the tourism and agricultural sector may vary regularly in the course of the year.

The potential predictability of flood hazard and risk varying at seasonal to decadal timescales opens the door to a dynamic risk management paradigm. Assume that one can quantify the climate mechanisms that result in changing flood characteristics over a certain future time period. Then one could use the projected statistics and their uncertainty distribution to provide information on risk reduction measures. For example, if one knows that a flood-rich period is active in a given region, and that one has to expect higher probabilities for damaging floods during the next few years, this knowledge can be used to optimize disaster management (optimized strategies in Fig. 8). Relief stocks and emergency capabilities could be temporarily increased, reservoir water levels could be temporarily lowered to allow for more flood retention volume, temporary levees could be built or floodplain zoning rules for different activities could be temporarily imposed. The predictability of the climate-flood link would allow for the portfolio of risk reduction measures to be optimized.

On the other hand, many future flood risk changes are expected to be severe but are not predictable. In such cases robustness is an important criterion for designing risk management strategies. Robustness describes how well a measure performs under different possible but initially uncertain future developments. Flood-proofing strategies - such as elevated configuration of buildings, sealing of buildings to prevent water entrance, or the use of building materials in such a

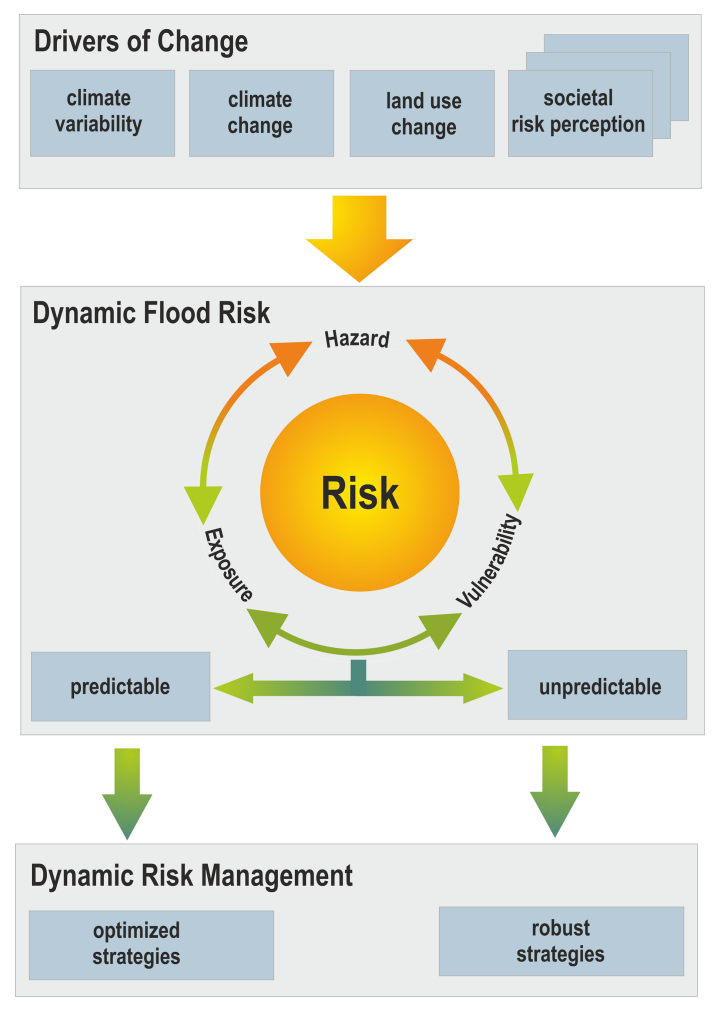

Figure 8. Drivers of flood risk change, dynamic risk and dynamic flood risk management.

way that the impact of inundation is minimized - are robust in the sense that these measures will lower the damage in the case of flooding, regardless of the exact future development of the flood hazard (Merz et al., 2010b). Another example is the enhancement of risk awareness and self-protecting behaviour of people at risk. If residents are aware of their flood risk and of their possibilities to undertake effective precautionary, adverse flood impacts will be reduced under different possible but initially uncertain future developments. Risk reduction measures that are designed to be robust differ from measures that are the result of an optimization for the most likely future development. They represent trade-offs and are associated with real or opportunity costs (Heltbert et al., 2009). Hence, the degree of predictability of future changes in flood hazard and risk influences the role that different criteria play in designing risk management measures (Blöschl et al., 2013).

As an example, consider seasonal flood forecasts in the insurance and reinsurance industry. Companies try to take short-term changes in loss probabilities into account in managing their lines of business. If, for instance, a wet year with above-average flood losses is expected in a certain region (such as in northeastern Australia during La Niña), less insurance may be offered to reduce accumulation risks. Apart from underwriting-related reactions on seasonal forecasts, preparation on high/low losses in terms of management of 
reserves may be done; short-term liquidity for flood losses can be raised or reduced. Also, reinsurers and insurers "like" to provide services to their clients in the form of recommendations based on the characteristics of the upcoming flood season, not least to show their expertise. The advantage the insurance sector derives from seasonal forecasts results from the fact that it does not deal with a specific, localized issue. For an emergency planner in a city, a shift in event probability of a few percent is almost meaningless; in the case of a (re-)insurance company, this shift concerns a whole portfolio with a large number of exposed items, and hence even a small shift in probability may be traced in the total amount of losses.

Although the dynamic flood risk management concept which considers climate-flood linkages is theoretically appealing, it is necessary to explore whether and in which regions these linkages constitute a sufficiently large part of the variability to be exploited in risk management strategies. Furthermore, how dynamic risk management could be implemented also needs to be explored. It would raise new questions, such as "what is the necessary change in flood probability for the coming season, and what is the necessary reliability with which this change can be quantified in order to impose floodplain zoning rules for certain activities?". Such questions need to be addressed against the given economic, legal and social environment.

\section{Conclusions: broader framing and global initiatives}

Traditionally, flood estimation and flood management have mainly been the domain of hydrologists, water resources engineers and statisticians, and disciplinary approaches abound. Embedding floods in the climate context, as laid out in this paper, requires the extension of this narrow framing. It is timely to bring together the different aspects of floods at the interfaces of the climate-catchment-society system. The discussions during the EGU topical meeting "Floods and Climate" converged to a common understanding that extending the perspectives in flood research opens up exciting possibilities for better understanding and for providing improved tools for flood risk assessment and management. The conclusions can be summarized as follows.

\subsection{Extend the system boundaries}

We argue for extending the traditional system boundaries (local catchment, recent decades, hydrological/hydraulic processes) in flood estimation and management. Extension in space goes beyond the inclusion of regional information which has proven beneficial in regional flood frequency analysis. Floods are embedded in global climate mechanisms, and deciphering these relations assures improvement in flood estimation and management, such as better understanding the tail behaviour of flood distributions or improved flood forecasting. However, it has been found that catchments respond rather differently to global climate variability (e.g. Glaser et al., 2010, for 12 major rivers in Europe for 1500-today). Hence, there exists a large variety of climateflood linkages, and the existence of a marked climate-flood relation within one catchment does not automatically allow for it to be transferred to other catchments in the same region. This extension of perspective concerns the temporal system boundaries as well. For example, new technological developments allow for reconstruction of millennial-scale flood time series differentiating between floods in different seasons. The integration of systematic measurements with historical and palaeodata offers exciting prospects for quantifying flood variability and extremes at very different timescales, from the decadal to the millennial timescale. Finally, it is noted that a richer understanding of floods requires considering the interplay of climate, geology, topography, vegetation (biology) and humans. Experiences, methods and data from a variety of scientific disciplines (e.g. meteorology, climatology, palaeohydrology, geography, economics) and from practitioners (e.g. insurance, disaster management and water authorities) need to be integrated.

\subsection{Understand the dominant processes}

We argue that different societal needs, such as flood estimation and forecasting, benefit from a better understanding of the processes that dominate the tail behaviour of flood distributions. Although statistical approaches have played and will play an important role, they have to be complemented by the search for the causal mechanisms and dominant processes in the atmosphere, catchment and river system that leave their fingerprints on flood characteristics. Understanding the dominant processes is expected to increase the reliability of extrapolation to rare floods and to reduce the potential for surprise. It is also an avenue for flood projections under climate change - complementing the widespread model chain approach. Understanding the different flood event types that occur in a given catchment and their dominant processes may provide an opportunity to hypothesize from a causal, mechanistic perspective about possible future flood changes. For example, spatial shifts in storm tracks or changes in the snowfall fraction may impact flood characteristics in certain ways. There is a need to develop processbased methods which can be applied by practitioners. One push in this direction are the guidelines on the estimation of flood probabilities, recently published by the German Water Association (DWA, 2012), which recommend the enhancement of extreme value statistics by incorporating hydrological understanding and additional data beyond the observed flood time series. 


\subsection{Quantify the role of natural variability}

One of the core concepts of this paper is that natural variability has an important role to play in flood estimation and flood management besides delivering the random component. We argue that flood characteristics vary in time, that this variation may be partially quantifiable and predictable, and that knowledge about this structured variability may be exploited in flood estimation and management. It is necessary to understand the ratio of structured variability to random variability, and how this ratio varies in space, with flood types, and with flood magnitude. For example, the structured variability for most regions in Europe is significantly lower than in the US. One task is to identify regions for which predictable climateflood links play a significant role and regions where randomness dominates. Another mainly open question is how the type and strength of climate-flood linkages vary with flood magnitude. Floods of different magnitudes may correspond to different climate modes (for an illustrative example, see Jain and Lall, 2000), and these variations need to be understood. Maybe the most important aspect is the persistence of climate-flood linkages: how stable are linkages between climate and floods? Results are mixed: for instance, floodfavouring circulation patterns have been found in many studies, but it has been found as well that different circulation patterns have dominated during different flood-rich periods of a given river (Schmocker-Faeckel and Naef, 2010). This is part of the more general discussion on the evidence of cycles in climate phenomena: as Burroughs (2003, p. 5) states in his comprehensive treatise on such cycles: “. . . a fundamental weakness of many apparently convincing examples of 'weather cycles': they come and go in a most tantalizing manner." The central question for a dynamic flood risk management concept which considers climate-flood linkages is whether these linkages constitute a sufficiently large part of the observed variability to be exploited in risk management strategies. Although there are some convincing examples, the potential of climate-informed risk management still needs to be explored.

\subsection{Integrate hazard with societal aspects}

Although the focus of this paper is on the role of climate, we stress the tremendous role of society. Ideally, risk assessment and management consider changes in hazard and societal aspects, and vary according to the predictability with which short- and long-term changes in flood risk can be quantified. Increasing efforts are needed to fully account for factors that contribute to changes in risk, which implies that changes in vulnerability (e.g. early warning, building codes) and exposure (e.g. population growth, spatial planning) need to be considered when interpreting records of observed flood losses. However, the understanding of the interplay between changes in hazard, exposure and vulnerability is hampered by data scarcity. The knowledge on disaster costs is incomplete and fragmented, with many cost types unaccounted for in current analyses, and a heavy focus on direct losses and less complete understanding of longer-term impacts and indirect costs (Merz et al., 2010b). While changes in the number of exposed assets and people can be reasonably well accounted for, temporal changes in vulnerability that are critically important are poorly understood and quantified. The interactions and feedbacks between society and floods are little understood. For instance, is the societal response to floods different for clustered events compared to random events? Here, we support the call for socio-hydrology which explicitly studies the co-evolution of humans and water (Sivapalan et al., 2012).

\subsection{Organize data and knowledge exchange globally}

The advancement of flood research in the discussed broader framework is fundamentally dependant on (1) access to and exchange of fit-for-purpose data on a global scale and (2) increased international and national collaboration between different disciplines, in particular hydrologists and meteorologists/climatologists. On a global level the identification of climate-driven changes in river flow is hindered due to a lack of long-term, high-quality data from rivers limited from artificial human disturbances (Whitfield et al., 2012). Therefore, in the past 15 years, several countries have established reference hydrologic networks (RHN) with the sole purpose of assessing hydrological responses to fluctuations in climate (Hannaford and Marsh, 2008; Whitfield et al., 2012; Murphy et al., 2013). Despite these efforts, the majority of regions across the globe have yet to establish such databases. Data users have a responsibility to promote the need of such data for their analyses in order to increase the global distribution of RHN-like networks. However, significant economic and institutional barriers to the open access to hydrometeorological data remain (Viglione et al., 2010; Hannah et al., 2011) and need to first be overcome. Hydrologists could learn from the climate community that actively advocate open data access and support data exchange (Hannah et al., 2011). Given the global scale and societal importance, we call for the organization of an international multidisciplinary collaboration and data-sharing initiative to understand further the links between climate and flooding. This would require the integration of meteorological, climatological and hydrological expertise in conjunction with increased access to coupled RHN and meteorological databases. While this is ambitious, discussions need to take place now for such an initiative to ever be realized even within medium-term flood risk planning horizons.

There have been some initiatives for studying floods in their global context. One of the earliest was the Natural Disaster Hotspots study of the World Bank (Arnold et al., 2005), which prepared a preliminary map of global flood hazard frequency, and examined mortality and economic risk. Recently, modelling efforts have been undertaken with the aim 
of assessing global flood hazard and risk (UNISDR, 2011; Hirabayashi et al., 2013; Ward et al., 2013; Winsemius et al., 2013). A different and very interesting path has been initiated by the earthquake risk community by launching the Global Earthquake Model (GEM, www.globalquakemodel. org). GEM is a collaborative effort and involves scientists and stakeholders from around the globe. Data, models, opensource software and knowledge are shared with the final aim of expanding the science of earthquake risk, informing decision making and increasing earthquake resilience worldwide. We feel that the flood research community should foster global approaches and should study physical and societal mechanisms of flooding within their global interconnectedness. This global perspective would not only improve our understanding and exploitation of linkages between climate and flooding but would also help in understanding and mitigating far-distance impacts of flooding, such as the disruption of global supply chains.

Acknowledgements. This paper is a result of the EGU topical meeting "Floods and Climate: Understanding and exploiting the link between floods and climate" held on 4-5 October 2012, at GFZ German Research Centre for Geosciences in Potsdam. Financial support for this meeting by the European Geosciences Union, AXA Research Fund, Free University Berlin and geo.X is gratefully acknowledged. We would like to acknowledge the support of the ERC advanced grant "FloodChange", project no. 291 152, and the Austrian Academy of Sciences (ÖAW) project "Mountain Floods".

The service charges for this open access publication

have been covered by a Research Centre of the

Helmholtz Association.

Edited by: P. Tarolli

Reviewed by: P. Willems and two anonymous referees

\section{References}

Abrahams, A. D. and Ponczynski, J. J.: Drainage density in relation to precipitation intensity in the USA, J. Hydrol., 75, 383-388, 1984.

Apel, H., Merz, B., and Thieken, A. H.: Influence of dike breaches on flood frequency estimation, Comput. Geosci., 35, 907-923, doi:10.1016/j.cageo.2007.11.003, 2009.

Arnbjerg-Nielsen, K., Willems, P., Olsson, J., Beecham, S., Pathirana, A., Gregersen, I. B., Madsen, H., and Nguyen, V.-T.V.: Impacts of climate change on rainfall extremes and urban drainage systems: a review, Water Sci. Technol., 68, 16-28, doi:10.2166/wst.2013.251, 2013.

Arnold, M., Dilley, M., Deichmann, U., Chen, R. S., and LernerLam, A. L.: Natural Disaster Hotspots: A Global Risk Analysis, World Bank, Washington, D.C., 2005.

Bachmair, S. and Weiler, M.: New dimensions of hillslope hydrology, in: Forest Hydrology and Biogeochemistry: Synthesis of Research and Future Directions, edited by: Levia, D., CarlyleMoses, D., and Tanaka, T., Springer Science + Business Media B.V., 455-481, 2011.
Baker, V. R.: Paleoflood hydrology: Origin, progress, prospects, Geomorphology, 101, 1-13, doi:10.1016/j.geomorph.2008.05.016, 2008.

Becker, A., Finger, P., Meyer-Christoffer, A., Rudolf, B., Schamm, K., Schneider, U., and Ziese, M.: A description of the global land-surface precipitation data products of the Global Precipitation Climatology Centre with sample applications including centennial (trend) analysis from 1901-present, Earth Syst. Sci. Data, 5, 71-99, doi:10.5194/essd-5-71-2013, 2013.

Benito, G., Sopena, A., Sanchez-Moya, Y., Machado, M. J., and Perez-Gonzalez, A.: Palaeoflood record of the Tagus River (Central Spain) during the Late Pleistocene and Holocene, Quaternary Sci. Rev., 22, 1737-1756, 2003a.

Benito, G., Díez-Herrero, A., and Fernández de Villalta, M.: Magnitude and frequency of flooding in the Tagus Basin (Central Spain) over the last millennium, Climatic Change, 58, 171-192, $2003 \mathrm{~b}$.

Bichet, A., Wild, M., Folini, D., and Schär, C.: Global precipitation response to changing forcings since 1870, Atmos. Chem. Phys., 11, 9961-9970, doi:10.5194/acp-11-9961-2011, 2011.

Bichet, A., Folini, D., Wild, M., and Schär, C.: Enhanced Central European summer precipitation in the late 19th century: a link to the Tropics, Q. J. Roy. Meteorol. Soc., 140, 111-123, doi:10.1002/qj.2111, 2014.

Blaikie, P. M. Cannon, T., Davis, I., and Wisner, B.: At Risk: Natural Hazards, People's Vulnerability and Disasters, Routledge, London, 1994.

Blöschl, G. and Merz, R.: Landform-hydrology feedbacks, in: Landform: Structure, Evolution, Process Control, edited by: Otto, J.-C. and Dikau, R., Springer, Wien, Heidleberg, 117-126, 2010.

Blöschl, G., Viglione, A., and Montanari, A.: Emerging approaches to hydrological risk management in a changing world, in: Climate Vulnerability, Chapter 5.05, edited by: Pielke, R. A., Sr., Elsevier Inc., Academic Press, 3-10, doi:10.1016/B978-0-12384703-4.00505-0, 2013.

Bouwer, L. M., Vermaat, J. E., and Aerts, J. C. J. H.: Winter atmospheric circulation and river discharge in northwest Europe, Geophys. Res. Lett., 33, L06403, doi:10.1029/2005GL025548, 2006.

Brazdil, R., Pfister, C., Wanner, H., Storch, H. V., and Luterbacher, J.: Historical climatology in Europe: the state of the art, Climatic Change, 70, 363-430, 2005.

Bronnimann, S.: Impact of El Nino - Southern Oscillation on European climate, Rev. Geophys., 45, RG3003, doi:10.1029/2006RG000199, 2007.

Bronstert, A., Bárdossy, A., Bismuth, C., Buiteveld, H., Disse, M., Engel, H., Fritsch, U., Hundecha, Y., Lammersen, R., Niehoff, D., and Ritter, N.: Multi-scale modelling of land-use change and river training effects on floods in the Rhine basin, River Res. Appl., 23, 1102-1125, 2007.

Bubeck, P., Botzen, W. J. W., and Aerts, J. C. J. H.: A review of risk perceptions and other factors that influence mitigation behaviour?, Risk Analysis, 32, 1481-1495, doi:10.1111/j.15396924.2011.01783.x, 2012.

Burroughs, W. J.: Weather Cycles, Real or Imaginary?, 2nd Edn., Cambridge University Press, 317 pp., 2003.

Cayan, D. R.: Interannual climate variability and snowpack in the Western United States, J. Climate, 9, 928-948, 1996. 
Cayan, D. R., Redmond, K. T., and Riddle, L. G.: ENSO and hydrologic extremes in the Western United States, J. Climate, 12, 2881-2893, 1999.

Cheng, Y., Tang, Y., and Chen, D.: Relationship between predictability and forecast skill of ENSO on various time scales, J. Geophys. Res., 116, C12006, doi:10.1029/2011JC007249, 2011.

Crompton, R. P. and McAneney, K. J.: Normalised Australian insured losses from meteorological hazards: 1967-2006, Environ. Sci. Policy, 11, 371-378, 2008.

Czymzik, M., Dulski, P., Plessen, B., von Grafenstein, U., Naumann, R., and Brauer, A.: A 450 year record of spring/summer flood layers in annually laminated sediments from Lake Ammersee (southern Germany), Water Resour. Res., 46, W11528, doi:10.1029/2009WR008360, 2010.

Dankers, R. and Feyen, L.: Flood hazard in Europe in an ensemble of regional climate scenarios, J. Geophys. Res.-Atmos., 114, D16108, doi:10.1029/2008JD011523, 2009.

Delgado, J. M., Merz, B., and Apel, H.: A climate-flood link for the lower Mekong River, Hydrol. Earth Syst. Sci., 16, 1533-1541, doi:10.5194/hess-16-1533-2012, 2012.

Delgado, J. M., Merz, B., and Apel, H.: Projecting flood hazard under climate change: an alternative approach to model chains, Nat. Hazards Earth Syst. Sci., 14, 1579-1589, doi:10.5194/nhess-141579-2014, 2014.

Di Baldassarre, G., Viglione, A., Carr, G., Kuil, L., Salinas, J. L., and Blöschl, G.: Socio-hydrology: conceptualising humanflood interactions, Hydrol. Earth Syst. Sci., 17, 3295-3303, doi:10.5194/hess-17-3295-2013, 2013.

DWA: Ermittlung von Hochwasserwahrscheinlichkeiten - Estimation of flood probabilities, DWA-Guidelines M 522, Hennef, Germany, 90 pp., 2012.

Ely, L., Enzel, Y., Baker, V. R., and Cayan, D. R.: A 5000-year record of extreme floods and climate change in the southwestern United States, Science, 262, 410-412, 1993.

Enzel, Y., Ely, L., House, P. K., Baker, V. R., and Webb, R. H.: Paleoflood evidence for a natural upper bound to flood magnitudes in the Colorado River Basin, Water Resour. Res., 29, 2287-2297, doi:10.1029/93WR00411, 1993.

Feyen, L., Dankers, R., Bódis, K., Salamon, P., and Barredo, J.: Fluvial flood risk in Europe in present and future climates, Climatic Change, 112, 47-62, doi:10.1007/s10584-011-0339-7, 2012.

Franks, S. W. and Kuczera, G.: Flood frequency analysis: Evidence and implications of secular climate variability, New South Wales, Water Resour. Res., 38, 1062, doi:10.1029/2001WR000232, 2002.

Gaál, L., Szolgay, J., Kohnová, S., Parajka, J., Merz, R., Viglione, A., and Blöschl, G.: Flood timescales: Understanding the interplay of climate and catchment processes through comparative hydrology, Water Resour. Res., 48, W04511, doi:10.1029/2011WR011509, 2012.

Gaetani, M., Baldi, M., Dalu, G. A., and Maracchi, G.: Jetstream and rainfall distribution in the Mediterranean region, Nat. Hazards Earth Syst. Sci., 11, 2469-2481, doi:10.5194/nhess-112469-2011, 2011.

Gergis, J. and Ashcroft, L.: Rainfall variations in south-eastern Australia, part 2: a comparison of documentary, early instrumental and paleoclimate records, 1788-2008, Int. J. Climatol., 33, 2973-2987, doi:10.1002/joc.3639, 2012.
Gilli, A., Anselmetti, F. S., Glur, L., and Wirth, S. B.: Lake sediments as archives of recurrence rates and intensities of past flood events, in: Dating torrential processes on fans and cones - Methods and their application for hazard and risk assessment, Advances in Global Change Research, edited by: SchneuwlyBollschweiler, M., Stoffel, M., and Rudolf-Miklau, F., Springer Science + Business Media, Dordrecht, 225-242, 2012.

Glaser, R., Riemann, D., Schönbein, J., Barriendos, M., Brázdil, R., Bertolin, C., Camuffo, D., Deutsch, M., Dobrovolný, P., van Engelen, A., Enzi, S., Halícková, M., Koenig, S. J., Kotyza, O., Limanówka, D., Macková, J., Sghedoni, M., Martin, B., and Himmelsbach, I.: The variability of European floods since AD 1500, Climatic Change, 101, 235-256, 2010.

Gregersen, I. B., Madsen, H., Rosbjerg, D., and Arnbjerg-Nielsen, K.: A spatial and non-stationary model for the frequency of extreme rainfall events, Water Resour. Res., 49, 127-136, doi:10.1029/2012WR012570, 2013.

Gumbel, E. J.: The return period of flood flows, Ann. Math. Stat., 12, 163-190, 1941.

Hall, J., Arheimer, B., Borga, M., Brázdil, R., Claps, P., Kiss, A., Kjeldsen, T. R., Kriauciunien, J., Kundzewicz, Z. W., Lang, M., Llasat, M. C., Macdonald, N., McIntyre, N., Mediero, L., Merz, B., Merz, R., Molnar, P., Montanari, A., Neuhold, C., Parajka, J., Perdigão, R. A. P., Plavcová, L., Rogger, M., Salinas, J. L., Sauquet, E., Schär, C., Szolgay, J., Viglione, A., and Blöschl, G.: Understanding flood regime changes in Europe: a state-ofthe-art assessment, Hydrol. Earth Syst. Sci., 18, 2735-2772, doi:10.5194/hess-18-2735-2014, 2014..

Hannaford, J. and Marsh, T. J.: High flow and flood trends in a network of undisturbed catchments in the UK, Int. J. Climatol., 28, 1325-1338, 2008.

Hannah, D. M., Demuth, S., van Lanen, H. A. J., Looser, U., Prudhomme, C., Rees, G., Stahl, K., and Tallaksen, L. M.: Large-scale river flow archives: importance, current status and future needs, Hydrol. Process., 25, 1191-1200, doi:10.1002/hyp.7794, 2011.

Heltbert, R., Siegel, P. B., and Jorgensen, S. L.: Addressing human vulnerability to climate change: Toward a "no-regrets" approach, Global Environ. Change, 19, 89-99, 2009.

Hess, P. and Brezowsky, H.: Katalog der Großwetterlagen Europas, Ber. Dt. Wetterd. in der US-Zone, Deutscher Wetterdienst, Offenbach, Germany, 39 pp., 1952.

Hirabayashi, Y., Roobavannan, M., Sujan, K., Lisako, K., Dai, Y., Satoshi, W., Hyungjun, K., and Shinjiro, K.: Global flood risk under climate change, Nat. Clim. Change, 3, 816-821, doi:10.1038/nclimate1911, 2013.

Hirschboeck, K. K.: Catastrophic flooding and atmospheric circulation anomalies, in: Catastrophic Flooding, edited by: Mayer, L. and Nash, D. B., Allen \& Unwin, Boston, 23-56, 1987.

Hirschboeck, K. K.: Flood hydroclimatology, in: Flood geomorphology, edited by: Baker, V. R., Kochel, R. C., and Pattern, P. C., Wiley, New York, 27-49, 1988.

House, P. K. and Hirschboeck, K. K.: Hydroclimatological and paleohydrological context of extreme winter flooding in Arizona, 1993, in: Storm-Induced Geological Hazards: Case Histories from the 1992-1993 Winter Storm in Southern California and Arizona, vol. XI, edited by: Larson, R. A. and Slosson, J. E., Geological Society of America Reviews in Engineering Geology, Boulder, Colorado, 1-24, 1997. 
IPCC: Managing the Risks of Extreme Events and Disasters to Advance Climate Change Adaptation, A Special Report of Working Groups I and II of the Intergovernmental Panel on Climate Change, Cambridge University Press, Cambridge, New York, 2012.

Jacobeit, J., Glaser, R., Luterbacher, J., and Wanner, H.: Links between flood events in central Europe since AD 1500 and largescale atmospheric circulation modes, Geophys. Res. Lett., 30, 1172, doi:10.1029/2002GL016433, 2003.

Jain, S. and Lall, U.: Magnitude and timing of annual maximum floods: Trends and large-scale climatic associations for the Blacksmith Fork River, Utah, Water Resour. Res., 36, 36413651, 2000.

Jain, S. and Lall, U.: Floods in a changing climate: Does the past represent the future?, Water Resour. Res., 37, 3193-3205, 2001.

Jongman, B., Ward, P. J., and Aerts, J. C. J. H.: Global exposure to river and coastal flooding: Long term trends and changes, Global Environ. Change, 22, 823-835, doi:10.1016/j.gloenvcha.2012.07.004, 2012.

Karamperidou, C., Cioffi, F., and Lall, U.: Surface temperature gradients as diagnostic indicators of midlatitude circulation dynamics, J. Climate, 25, 4154-4171, 2012.

Karamperidou, C., Cane, M. A., Lall, U., and Wittenberg, A. T.: Intrinsic modulation of ENSO predictability viewed through a local Lyapunov lens, Clim. Dynam., 25, 4154-4171, 2013.

Kay, A. L., Davies, H. N., Bell, V. A., and Jones, R. G.: Comparison of uncertainty sources for climate change impacts: flood frequency in England, Climatic Change, 92, 41-63, 2009.

Kendon, E., Roberts, N., Fowler, H. J., Roberts, M., Chan, S. C., and Senior, C.: Heavier summer downpours with climate change revealed by weather forecast resolution model, Nat. Clim. Change, 4, 570-576, doi:10.1038/nclimate2258, 2014.

Kiem, A. S., Franks, S. W., and Kuczera, G.: Multi-decadal variability of flood risk, Geophys. Res. Lett., 30, 1035, doi:10.1029/2002GL015992, 2003.

Kingston, D. G., Lawler, D. M., and McGregor, G. R.: Linkages between atmospheric circulation, climate and streamflow in the northern North Atlantic: Research prospects, Prog. Phys. Geogr., 30, 143-174, 2006.

Knox, J. C.: Sensitivity of modern and Holocene floods to climate change. Quaternary Sci. Rev., 19, 439-457, 2000.

Kochel, R. C. and Baker, V. R.: Paleoflood hydrology, Science, 215, 353-361, doi:10.1126/science.215.4531.353, 1982.

Kreibich, H., Seifert, I., Thieken, A. H., Lindquist, E., Wagner, K., and Merz, B.: Recent changes in flood preparedness of private households and businesses in Germany, Reg. Environ. Change, 11, 59-71, doi:10.1007/s10113-010-0119-3, 2011.

Kuhlicke, C., Scolobig, A., Tapsell, S., Steinführer, A., and de Marchi, B.: Contextualizing social vulnerability: Findings from case studies across Europe, Nat. Hazards, 58, 789-810, 2011.

Kumar, P.: Variability, feedback, and cooperative process dynamics: elements of a unifying hydrologic theory, Geogr. Compass, 1, 1338-1360, doi:10.1111/j.1749-8198.2007.00068.x, 2007.

Kundzewicz, Z. W., Ulbrich, U., Brucher, T., Graczyk, D., Kruger, A., Leckebusch, G. C., Menzel, L., Pinskwar, I., Radziejewski, M., and Szwed, M.: Summer floods in central europe - climate change track?, Nat. Hazards, 36, 165-189, 2005.
Kwon, H.-H., Brown, C., and Lall, U.: Climate informed flood frequency analysis and prediction in Montana using hierarchical Bayesian modeling, Geophys. Res. Lett., 35, L05404, doi:10.1029/2007GL032220, 2008.

Levish, D. R.: Paleohydrologic bounds-nonexceedance information for flood hazard assessment, in: Ancient Floods, Modern Hazards: Principles and Applications of Paleoflood Hydrology, vol. 5, edited by: House, P. K., Webb, R. H., Baker, V. R., and Levish, D. R., American Geophysical Union Water Science and Application Series, American Geophysical Union, Washington, D.C., 175-190, 2002.

Lin, Z., Levy, J. K., Xu, X., Zhao, S., and Hartmann, J.: Weather and seasional climate prediction for flood planning in the Yangtze River Basin, Stoch. Environ. Res. Risk Assess., 19, 428-437, 2005.

Mangili, C., Brauer, A., Moscariello, A., and Naumann, R.: Microfacies of detrital event layers deposited in Quaternary varved lake sediments of the Piànico-Sèllere Basin (northern Italy), Sedimentology, 52, 927-943, 2005.

Maraun, D., Rust, H. W., and Osborn, T. J.: Synoptic airflow and UK daily precipitation extremes: Development and validation of a vector generalised linear model, Extremes, 13, 133-153, doi:10.1007/s10687-010-0102-x, 2010.

Merz, R. and Blöschl, G.: Flood Frequency Hydrology 1: Temporal, spatial and causal expansion of information, Water Resour. Res., 44, W08432, doi:10.1029/2007WR006744, 2008a.

Merz, R. and Blöschl, G.: Flood Frequency Hydrology 2: Combining data evidence, Water Resour. Res., 44, W08433, doi:10.1029/2007WR006745, 2008b.

Merz, B., Hall, J., Disse, M., and Schumann, A.: Fluvial flood risk management in a changing world, Nat. Hazards Earth Syst. Sci., 10, 509-527, doi:10.5194/nhess-10-509-2010, 2010 a.

Merz, B., Kreibich, H., Schwarze, R., and Thieken, A.: Review article "Assessment of economic flood damage", Nat. Hazards Earth Syst. Sci., 10, 1697-1724, doi:10.5194/nhess-10-16972010, 2010b.

Moss, R. H., Babiker, M., Brinkman, S., Calvo, E., Carter, T., Edmonds, J., Elgizouli, I., Emori, S., Erda, L., Hibbard, K., Jones, R., Kainuma, M., Kelleher, J., Lamarque, J. F., Manning, M., Matthews, B., Meehl, J., Meyer, L., Mitchell, J., Nakicenovic, N., O’Neill, B., Pichs, R., Riahi, K., Rose, S., Runci, P., Stouffer, R., van Vuuren, D., Weyant, J., Wilbanks, T., van Ypersele, J. P., and Zurek, M.: Towards new scenarios for analysis of emissions, climate change, impacts and response strategies, Technical Summary, Intergovernmental Panel on Climate Change, Geneva, 25 pp., 2008.

Moss, R. H., Edmonds, J. A., Hibbard, K. A., Manning, M. R., Rose, S. K., van Vuuren, D. P., Carter, T. R., Emori, S., Kainuma, M., Kram, T., Meehl, G. A., Mitchell, J. F. B., Nakicenovic, N., Riahi, K., Smith, S. J., Stouffer, R. J., Thomson, A. M., Weyant, J. P., and Wilbanks, T. J.: The next generation of scenarios for climate change research and assessment, Nature, 463, 747-756, doi:10.1038/nature08823, 2010.

Mudelsee, M., Deutsch, M., Borngen, M., and Tetzlaff, G.: Trends in flood risk of the River Werra (Germany) over the past 500 years, Hydrolog. Sci. J., 51, 818-833, 2006.

Murphy, C., Harrigan, S., Hall, J., and Wilby, R. L.: Climate-driven trends in mean and high flows from a network of reference stations in Ireland, Hydrolog. Sci. J., 58, 755-772, 2013. 
Murphy, P.: Evaluation of mixed-population flood frequency analysis, J. Hydrol. Eng., 6, 62-70, 2001.

Nakamura, J., Lall, U., Kushnir, Y., Robertson, A. W., and Seager, R.: Dynamical structure of extreme floods in the U.S. Midwest and the United Kingdom, J. Hydrometeorol., 14, 485-504, doi:10.1175/JHM-D-12-059.1, 2013.

Nakicenovic, N. and Swart, R.: IPCC Special Report on Emissions Scenarios, Cambridge University Press, Cambridge, UK, 570 pp., 2000.

Nied, M., Hundecha, Y., and Merz, B.: Flood-initiating catchment conditions: a spatio-temporal analysis of large-scale soil moisture patterns in the Elbe River basin, Hydrol. Earth Syst. Sci., 17, 1401-1414, doi:10.5194/hess-17-1401-2013, 2013.

Ott, I., Duethmann, D., Liebert, J., Berg, P., Feldmann, H., Ihringer, J., Kunstmann, H., Merz, B., Schaedler, G., and Wagner, S.: High-Resolution Climate Change Impact Analysis on MediumSized River Catchments in Germany: An Ensemble Assessment, J. Hydrometeorol., 14, 1175-1193, doi:10.1175/JHM-D12-091.1, 2013.

Petrow, T., Thieken, A. H., Kreibich, H., Merz, B., and Bahlburg, C. H.: Improvements on flood alleviation in Germany: Lessons learned from the Elbe flood in August 2002, Environ. Manage., 38, 717-732, doi:10.1007/s00267-005-6291-4, 2006.

Pfister, C.: Wetternachhersage 500 Jahre Klimavariationen und Naturkatastrophen (1496-1995), Phaupt, Bern, 1999.

Philipp, A., Della-Marta, P. M., Jacobeit, J., Fereday, D. R., Jones, P. D., Moberg, A., and Wanner, H.: Long-term variability of daily north atlantic-european pressure patterns since 1850 classified by simulated annealing clustering, J. Climate, 20, 4065-4095, 2007.

Pilgrim, D. H. and Cordery, I.: Flood Runoff, in: HandBook of Hydrology, International Edn., Chap. 9, edited by: Maidment, D. R., McGraw-Hill, Inc., New York, USA, 42 pp., 1993.

Pinto, J. G., Ulbrich, S., Parodi, A., Rudari, R., Boni, G., and Ulbrich, U.: Identification and ranking of extraordinary rainfall events over Northwest Italy: The role of Atlantic moisture, J. Geophys. Res.-Atmos., 118, 2085-2097, doi:10.1002/jgrd.50179, 2013.

Pizarro, G. and Lall, U.: El Nino and floods in the U.S. West: What can we expect?, EOS Trans. AGU, 83, 349-352, 2002.

Pizarro, G., Lall, U., and Atallah, M.: Tracking the Indexes, Weather Risk, Financial Engineering Ltd., London, 2009.

Prudhomme, C., Wilby, R. L., Crooks, S., Kay, A. L., and Reynard, N. S.: Scenario-neutral approach to climate change impact studies: Application to flood risk, J. Hydrol., 390, 198-209, 2010.

Rana, A., Uvo, C. B., Bengtsson, L., and Sarthi, P. P.: Trend analysis for rainfall in Delhi and Mumbai, India, Clim. Dynam., 38, 1-2, 45-56, doi:10.1007/s00382-011-1083-4, 2011.

Raupach, M. R.: Simplicity, complexity and scale in terrestrial biosphere modelling, in: Predictions in Ungauged Basins: International Perspectives on the State-of-the-Art and Pathways Forward, edited by: Franks, S.,Sivapalan, M., Takeuchi, K., and Tachikawa, Y., IAHS Publication 301, IAHS, Wallingford, 239274, 2005 .

Rihani, S.: Complex Systems Theory and Development Practice: Understanding Non-Linear Realities, Zed Books, London, 2002.

Rogger, M., Pirkl, H., Viglione, A., Komma, J., Kirnbauer, R., Merz, R., and Blöschl, G.: Step changes in the flood frequency curve - process controls, Water Resour. Res., 48, W05544, doi:10.1029/2011WR011187, 2012.
Rudari, R., Entekhabi, D., and Roth, G.: Large-scale atmospheric patterns associated with mesoscale features leading to extreme precipitation events in Northwestern Italy, Adv. Water Resour., 28, 601-614, 2005.

Sankarasubramanian, A. and Lall, U.: Flood quantiles in a changing climate: Seasonal forecasts and causal relations, Water Resour. Res., 39, 1134, doi:10.1029/2002WR001593, 2003.

Schmocker-Fackel, P. and Naef, F.: Changes in flood frequencies in Switzerland since 1500, Hydrol. Earth Syst. Sci., 14, 1581-1594, doi:10.5194/hess-14-1581-2010, 2010.

Schneider, U., Becker, A., Finger, P., Meyer-Christoffer, A., Rudolf, B., and Ziese, M.: GPCC Full Data Reanalysis Version 6.0 at $0.5^{\circ}$ : Monthly Land-Surface Precipitation from Rain-Gauges built on GTS-based and Historic Data, Global Precipitation Climatology Centre, GPCC, http:// gpcc.dwd.de/ at Deutscher Wetterdienst, Offenbach, Germany, doi:10.5676/DWD_GPCC/FD_M_V6_050, 2011.

Serinaldi, F. and Kilsby, C. G.: Rainfall extremes: Toward reconciliation after the battle of distributions, Water Resour. Res., 50, 336-352, 2014.

Shin, S. I. and Sardeshmukh, P. D.: Critical influence of the pattern of Tropical Ocean warming on remote climate trends, Clim. Dynam., 36, 1577-1591, 2011.

Sivapalan, M., Blöschl, G., Merz, R., and Gutknecht, D.: Linking flood frequency to long-term water balance: Incorporating effects of seasonality, Water Resour. Res., 41, W06012, doi:10.1029/2004WR003439, 2005.

Sivapalan, M., Savenije, H. H. G., and Blöschl, G.: Sociohydrology: A new science of people and water, Hydrol. Process., 26, 1270-1276, doi:10.1002/hyp.8426, 2012.

Steinbrich, A. and Weiler, M.: Ausweisung der für die Hochwasserentstehung wichtigen Abflussbildungsprozesse für BadenWürttemberg, in: Forum für Hydrologie und Wasserbewirtschaftung Hydrologische Wissenschaften, Fachgemeinschaft in der DWA, edited by: Caspar, M. and Gronz, O., Hennef, Germany, 171-185, 2012.

Swierczynski, T., Brauer, A., Lauterbach, S., Martín-Puertas, C., Dulski, P., von Grafenstein, U., and Rohr, C.: A $1600 \mathrm{yr}$ seasonally resolved record of decadal-scale flood variability from the Austrian Pre-Alps, Geology, 40, 1047-1050, doi:10.1130/G33493.1, 2012.

Swierczynski, T., Lauterbach, S., Dulski, P., Delgado, J., Merz, B., and Brauer, A.: Mid- to late Holocene flood frequency changes in the northeastern Alps as recorded in varved sediments of Lake Mondsee (Upper Austria), Quaternary Sci. Rev., 80, 7890, 2013.

Tobin, G. A.: The levee love affair: A stormy relationship, Water Resour. Bull., 31, 359-367, 1995.

Todhunter, P.: Uncertainty of the Assumptions Required for Estimating the Regulatory Flood: Red River of the North, J. Hydrol. Eng., 17, 1011-1020, 2012.

Toreti, A., Xoplaki, E., Maraun, D., Kuglitsch, F. G., Wanner, H., and Luterbacher, J.: Characterisation of extreme winter precipitation in Mediterranean coastal sites and associated anomalous atmospheric circulation patterns, Nat. Hazards Earth Syst. Sci., 10, 1037-1050, doi:10.5194/nhess-10-1037-2010, 2010.

Tucker, G. and Bras, R.: A stochastic approach to modeling the role of rainfall variability in drainage basin evolution, Water Resour. Res., 36, 1953-1964, 2000. 
UNISDR: Global Assessment Report on Disaster Risk Reduction 2011, Revealing Risk, Redefining Development, United Nations International Strategy for Disaster Reduction Secretariat, Geneva, 2011.

UNISDR: Global Assessment Report on Disaster Risk Reduction 2013, From Shared Risk to Shared Value: the Business Case for Disaster Risk Reduction, United Nations International Strategy for Disaster Reduction Secretariat, Geneva, 2013.

Viglione, A. and Blöschl, G.: On the role of storm duration in the mapping of rainfall to flood return periods, Hydrol. Earth Syst. Sci., 13, 205-216, doi:10.5194/hess-13-205-2009, 2009.

Viglione, A., Borga, M., Balabanis, P., and Blöschl, G.: Barriers to the exchange of hydrometeorological data in Europe: Results from a survey and implications for data policy, J. Hydrol., 394, 63-77, 2010.

Ward, P. J., Beets, W., Bouwer, L. M., Aerts, J. C. J. H., and Renssen, H.: Sensitivity of river discharge to ENSO, Geophys. Res. Lett., 37, L12402, doi:10.1029/2010GL043215, 2010.

Ward, P. J., Jongman, B., Sperna Weiland, F., Bouwman, A., Van Beek, R., Bierkens, M. F. P., Ligtvoet, W., and Winsemius, H. C.: Assessing flood risk at the global scale: model setup, results, and sensitivity, Environ. Res. Lett., 8, 044019, doi:10.1088/17489326/8/4/044019, 2013.

Ward, P. J., Van Pelt, S. C., De Keizer, O., Aerts, J. C. J. H., Beersma, J. J., Van den Hurk, B. J. J. M., and Te Linde, A.: Including climate change projections in probabilistic flood risk assessment, J. Flood Risk Manage., 7, 141-151, doi:10.1111/jfr3.12029, 2014a.

Ward, P. J., Eisner, S., Flörke, M., Dettinger, M. D., and Kummu, M.: Annual flood sensitivities to El Niño-Southern Oscillation at the global scale, Hydrol. Earth Syst. Sci., 18, 47-66, doi:10.5194/hess-18-47-2014, 2014b.

Waylen, P. R. and Caviedes, C. N.: El Niño and annual floods on the north Peruvian littoral, J. Hydrol., 89, 141-156, 1986.
Weiler, M., Scheffler, C., Tautz, A., and Rosin, K.: Development of a hydrologic process model for mountain pine beetle affected areas in British Columbia, Report to the Fraser Salmon and Watersheds Program, Pacific Salmon Foundation, Vancouver, 2009.

Whitfield, P. H., Burn, D. H., Hannaford, J., Higgins, H., Hodgkins, G. A., Marsh, T., and Looser, U.: Reference hydrologic networks I. The status and potential future directions of national reference hydrologic networks for detecting trends, Hydrolog. Sci. J., 57, 1562-1579, 2012.

Wilhelm, B., Arnaud, F., Sabatier, P., Crouzet, C., Brisset, E., Chaumillon, E., Disnar, J. R., Guiter, F., Malet, E., Reyss, J. L., Tachikawa, K., Bard, E., and Delannoy, J. J.: 1400 years of extreme precipitation patterns over the Mediterranean French Alps and possible forcing mechanisms, Quaternary Res., 78, 1-12, 2012.

Wilhelm, B., Arnaud, F., Sabatier, P., Magand, O., Chapron, E., Courp, T., Tachikawa, K., Fanget, B., Malet, E., Pignol, C., Bard, E., and Delannoy, J. J.: Palaeoflood activity and climate change over the last 1400 years recorded by lake sediments in the NW European Alps, J. Quaternary Sci., 28, 189-199, 2013.

Willems P.: Multidecadal oscillatory behaviour of rainfall extremes in Europe, Climatic Change, 120, 931-944, 2013.

Winsemius, H. C., Van Beek, L. P. H., Jongman, B., Ward, P. J., and Bouwman, A.: A framework for global river flood risk assessments, Hydrol. Earth Syst. Sci., 17, 1871-1892, doi:10.5194/hess-17-1871-2013, 2013.

Zaalberg, R. and Midden, C. J. H.: Living behind dikes: mimicking flooding experiences, Risk Anal., 33, 866-876, doi:10.1111/j.1539-6924.2012.01868.x, 2013.

Zhang, Q., Xu, C.-Y., Jiang, T., and Wu, Y.: Possible influence of ENSO on annual maximum streamflow of the Yangtze River, China, J. Hydrol., 333, 265-274, 2007. 